\title{
Purified Monocyte-derived Angiogenic Substance (Angiotropin) Induces Controlled Angiogenesis Associated with Regulated Tissue Proliferation in Rabbit Skin
}

\author{
Michael Höckel, „‡ Walter Jung," Peter Vaupel," Hartmut Rabes," Cyrus Khaledpour,' and Josef H. Wissler \\ *Universitätsfrauenklinik, D-6500 Mainz, West Germany ${ }^{\ddagger}$ Harvard Medical School, Departments of Surgery and Pathology, \\ Massachusetts General Hospital, Boston, Massachusetts 02114; $\$$ Abteilung Angewandte Physiologie der Universität, D-6500 Mainz, \\ West Germany, and Harvard Medical School, Massachusetts General Hospital Cancer Center, Department of Radiation Medicine, \\ Boston, Massachusetts 02114; "Abteilung Experimentelle Pathologie der Universität, D-8000 München, West Germany; \\ 'Anatomisches Institut der Universität, D-6500 Mainz, West Germany; Abteilung Biochemie Supramolekularer Strukturen, \\ Institut für Physiologische Chemie, Ruhr Universität D-4630 Bochum, West Germany
}

\begin{abstract}
Angiotropin is a differentiation factor for microvascular endothelial cells isolated from serum-free cultures of lectin-activated, porcine monocytes. We used an ear lobe model in rabbits, single intradermal injection of angiotropin to induce phenotypical changes of the endothelial cells in capillaries and postcapillary venules, vascular engorgement, and subsequent angiogenesis in dose-dependent manner. The vascular changes are associated with epidermal and stromal cell proliferation. Angiogenesis and tissue proliferation occur in the absence of tissue necrosis and do not lead to scar formation. Angiotropininduced angiogenesis is not inhibited by local dexamethasone although it involves a defined turnover of inflammatory cells. Proliferation is transient and regressive events follow. The overall tissue reaction resembles changes found in the undamaged skin margin of a primary healing wound during the inflammatory/proliferative phase. From these observations we conclude that angiotropin is an important secretory product of activated peripheral macrophages that triggers inflammatory and proliferative reactions in wound healing by activating microvascular endothelial cells.
\end{abstract}

\section{Introduction}

Gross tissue injury or a wound stimulate angiogenesis as well as epithelial and stromal hyperplasia in the wound margins concomitant to the regeneration or repair of the damaged tissue. The biological mechanisms of the rapid induction and regulation of these processes are largely unknown. According to the chalone theory, a loss of an inhibitor was claimed for the epidermal proliferation in a skin wound (1). Other investigators postulated diffusible, activating mediators as paracrine wound hormones (2-4). From numerous observations using rabbit ear chambers, the Clarks (1939) hypothesized the existence of a chemical stimulus not only for vascular growth but

Address reprint requests to Dr. Michael Höckel, Universitätsfrauenklinik, Langenbeckstrasse 1, D-6500 Mainz, West Germany.

Received for publication 30 July 1987 and in revised form 4 February 1988.

J. Clin. Invest.

(c) The American Society for Clinical Investigation, Inc. 0021-9738/88/09/1075/16 \$2.00

Volume 82, September 1988, 1075-1090 also for growth promotion of lymphatics, nerves, connective and other tissues in wound healing (5). Modulation of the extracellular matrix (including basement membranes) by enzymatic activities might also contribute to the regulation of cellular proliferation (6).

Based on a series of experiments, activated monocytes/ macrophages have been claimed to be involved in the regulation of tissue regeneration or repair (7-10). Animals depleted of monocytes/macrophages show a delay in wound healing $(11,12)$. Activated macrophages stimulate collagen synthesis in vivo (12), as well as endothelial growth and neovascularization in the cornea (12-14). In 1976, Leibovich and Ross (15) described the macrophage-derived growth factor (MDGF), which was partially purified from conditioned media of activated macrophages $(16,17)$. MDGF, which seems to be related to the basic fibroblast growth factor (bFGF) (18), stimulates the growth of fibroblasts as well as smooth muscle and endothelial cells in vitro (15-17). Studies by Knighton et al. $(19,20)$ suggest that activated macrophages may induce angiogenesis by secretion of nonmitogenic factor(s). In 1981, Wissler isolated a copper-containing polyribonucleopolypeptide from large-scale cultures of peripheral porcine monocytes that had been activated by concanavalin $\mathrm{A}$. This substance was designated "angiotropin" because of its strong angiogenic effects in the rabbit cornea and in the chicken chorioallantoic membrane $(21,22)$. We have recently shown that angiotropin stimulates the differentiation of cloned capillary endothelial cells in vitro by changing their phenotype from a monolayer of epitheloid, polygonal cells on gelatin-coated dishes into migrating "sprout cells," which organize spatially into tube-like structures. Angiotropin also promotes the migration of single capillary endothelial cells but does not stimulate the proliferation of these cells in nonconfluent cultures. BALB/c3T3 fibroblasts do not proliferate, migrate, or differentiate in the presence of angiotropin (23). Angiotropin is a macrophage-derived product that shows unusual chemical and biological properties and appears to be distinct from fibroblast growth factor (FGF) and other known angiogenic polypeptides.

We describe the in vivo effects of single bolus injection of angiotropin into rabbit ear skin. We present evidence that angiotropin induces endothelial activation associated with endothelial hyperplasia, neovascularization, epidermal hyperplasia, and fibroblast proliferation in a dose-dependent manner. These tissue reactions, which show striking similarities with the inflammatory-proliferative phase in wound healing, occur in the virtual absence of preceding tissue destruction and do not result in scar formation. 


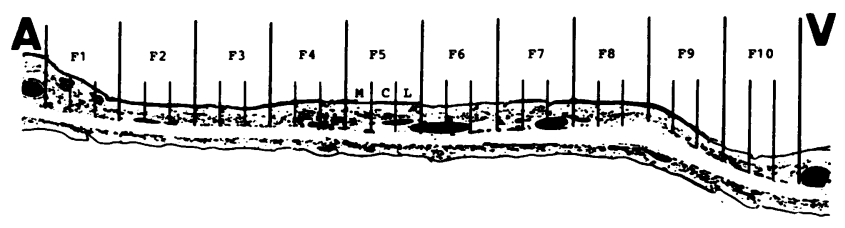

Figure 1. Transverse section through the lateral part of a rabbit's ear lobe subdivided for the morphometrical analysis of the microvessels in the dorsal skin between central artery $(A)$ and lateral vein $(V)$. Before histologic processing the rabbit ear lobes were perfused with dextran 60 followed by filtered india ink. Each unit field (F1-F10) was further divided into a medial $(M)$, central $(C)$ and lateral $(L)$ subfield; $\times 3$.

\section{Methods}

Animals. Adult, long-eared New Zealand white rabbits of both sexes weighing 3-4 kg were used in this study. The animals were kept at 12-h light and dark cycles at $20^{\circ} \mathrm{C}$ and received rabbit chow and water ad lib.

Intradermal injections. After removing the hair with a depilatory (Pilca, Olivin, Hamburg, FRG) intradermal injections were made into the dorsal skin of the upper half of the ear lobe in the area between the central artery and the lateral vein. As a rule the homologous site of the contralateral ear was used for injection of control substances.

To minimize the trauma that results from injection, the following technique was used: a sterile $50 \mu$ l glass syringe (Hamilton, Bonaduz, Switzerland) was equipped with a 31-gauge needle. A shorter 26-gauge needle was first inserted into the epidermis at a low angle to serve as trocar, and then the 31-gauge needle was directed through the trocar and pushed forward into the dermis for $\sim 2 \mathrm{~mm}$. The standard $50-\mu \mathrm{l}$ aliquot injection produced a transient papule of $\sim 1 \mathrm{~cm}$ in diameter. Before the injection, the rabbits were anesthetized with $5 \mathrm{mg} / \mathrm{kg}$ of xylazine i.m. (Rompun, Bayer, Leverkusen, FRG) together with 30 $\mathrm{mg} / \mathrm{kg}$ of ketamine i.m. (Ketanest, Parke Davis, München, FRG). The ear lobe was disinfected with povidone iodine solution before injection.

All solutions used for injection were sterile and pyrogen free. Saline or PBS (pH 7.4; Gibco Laboratories, Grand Island, NY), which contained $25 \mu \mathrm{g} / \mathrm{ml}$ of porcine serum albumin (Pel-freeze Corp., Chicago, IL) highly (99\%) purified by gel filtration on Sephadex G75 and anion exchange chromatography on DEAE-Sephadex A50) was usually in- jected as the control solution. The following substances were also used for control intradermal injections: dexamethasone-21-acetate (Merck, Darmstadt, FRG) as crystal suspension and in a novel biodegradable therapeutic system for sustained release (Sandoz, Basel, Switzerland), porcine anaphylatoxin (24), porcine cocytotaxin (24), prostaglandin $E_{2}$ (Minprostin $E_{2}$, Upjohn, Heppenheim, FRG), histamine (Sigma Chemical Co., St. Louis, MO), concanavalin A (Serva, Heidelberg, FRG), salt-free water (Fresenius, Bad Homburg, FRG), $\mathrm{NaCl}, 1.5 \mathrm{M}$, formic acid, sodium hydroxid (all from Merck), pentobarbital (Nembutal, Ceva, France), Wissler medium (BM-86 Wissler; Boehringer, Mannheim, FRG).

Angiotropin. The isolation, purification, and chemical characterization of angiotropin have been described elsewhere (21-23). The angiotropin preparation used in this study was shown to migrate as a single band in SDS-PAGE and to possess no endotoxin-like activity in the rabbit fever test according to the US Pharmacopeia. It was stored as frozen stock solution $(50 \mathrm{ng} / \mathrm{ml}$ dissolved in PBS containing $1 \mathrm{mM}$ $\mathrm{L}$-cysteine and $3.65 \mu \mathrm{M}$ pyrogen-free porcine serum albumin as carrier protein). Thawed aliquots of this stock solution were diluted with either sterile pyrogen-free saline or PBS before intradermal injection.

Perfusion. For perfusion of the ear lobes the animals were anesthetized by the intramuscular xylazine/ketamine regimen. The rabbits were placed on a heating pad (rectal temperature, $37^{\circ} \mathrm{C}$ ), and after skin incision, the right crural artery was freed from its adventitia sheet, cannulated with a polyethylene catheter (o.d. $1.5 \mathrm{~mm}$, i.d. $1.0 \mathrm{~mm}$ ) and ligated distally. By this vascular access, heparin (350 U.S.Pharmacopeia-U/kg) in saline was given followed by $1 \mathrm{ml} / \mathrm{kg}$ of a $25 \%$ urethane solution to maintain surgical anesthesia. Afterwards, both carotid arteries were exposed from a midline skin incision in the ventral neck area and polyethylene catheters (o.d. $1.5 \mathrm{~mm}$, i.d. $1.0 \mathrm{~mm}$ ) filled with heparin solution were introduced proximal from the origin of the auricular arteries. Both carotid catheters were connected to a pulsatile pump (Infusomat, type 870202; Braun, Melsungen, FRG) via a Tconnector and to a Statham pressure transducer (type P 23 ID, Gould Instruments, Houston, TX), which was linked to a pressure monitor (type SP 1400, Gould) through a second T-connector. Immediately after cannulation of the carotid arteries, perfusion with a dextran 60 plasma expander (Macrodex 6\%, Knoll, Ludwigshafen, FRG) was started. The dextran solution was pumped into the carotid arteries at a flow rate to keep the mean arterial pressure at $100-120 \mathrm{mmHg}$. During the perfusion period aliquots of blood were withdrawn through the catheter in the crural artery. After exchange of $300-400 \mathrm{ml}$, the ani-
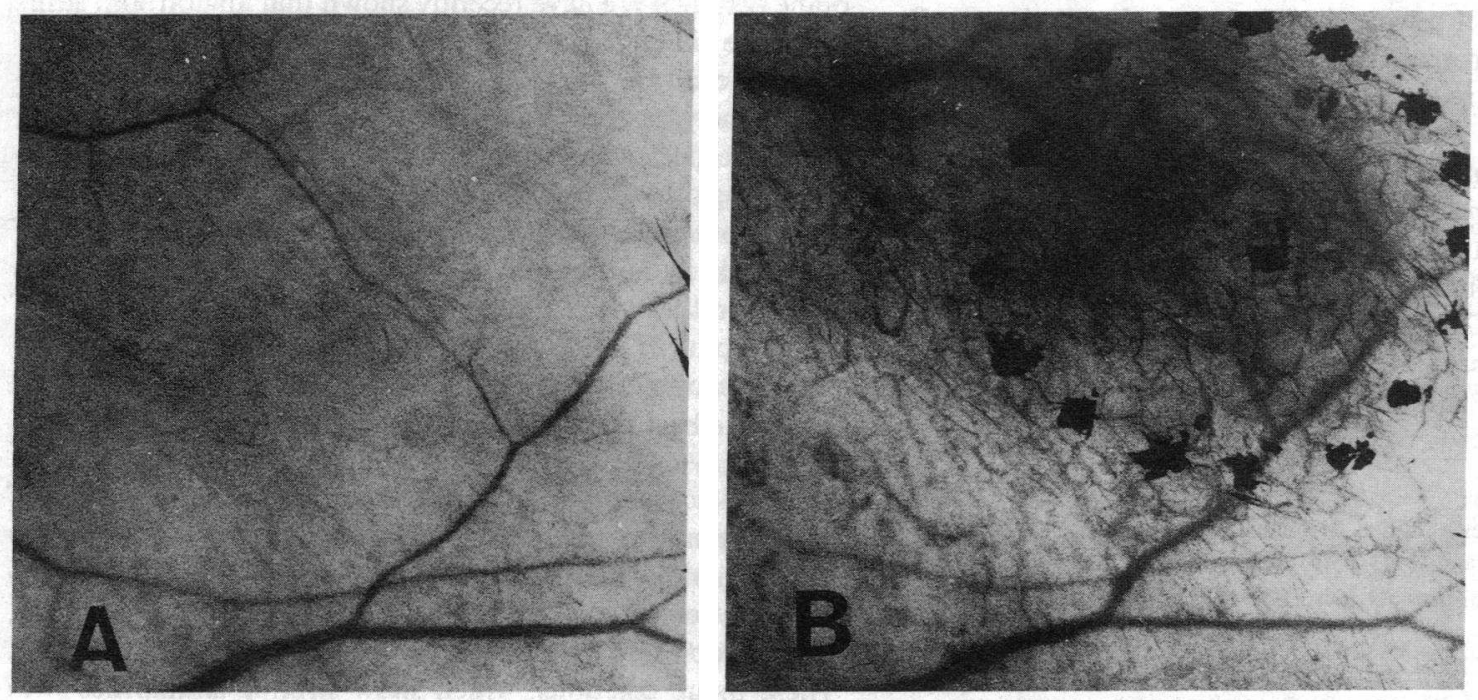

Figure 2. Change of angioarchitecture in the dorsal skin of the rabbit's ear lobe $48 \mathrm{~h}$ after intradermal injection of $125 \mathrm{pg}$ of angiotropin as seen macroscopically in transmission light $(B)$ compared with the pretreatment state $(A) ; \times 4$. The site of injection and the extension of the initial skin papule produced by the intradermal injection are indicated. 
mals came ad exitum. After perfusion of another $300 \mathrm{ml}$ of dextran solution the ear lobes were completely free of blood. $100 \mathrm{ml}$ of an india ink gelatine solution were perfused at $100-120 \mathrm{mmHg}$. This solution was prepared by adding $75 \mathrm{ml}$ of filtered india ink (Pelikan, Hannover, FRG) to $25 \mathrm{ml}$ of an aqueous $10 \%$ gelatine (Merck). To exclude particle diameters exceeding $5 \mu \mathrm{m}$, filtration of the india ink was performed with an industrially designed set up (Merkur EF, Seitz-Enzinger-Noll, Bad Kreuznach, FRG), equipped with cellulose-polyester membranes (Supra 500, Seitz-Filter Werke, Bad Kreuznach, FRG).

After perfusion, the ear lobes were removed and the areas of the angiotropin and control injections were photographed using transmission light with a 50-mm f/4 macrolens combined with a No. 2 close up lens. The ear lobes were then fixed in $10 \%$ phosphate-buffered formalin for histological processing. Using this perfusion technique the lumina of all blood vessels of the rabbit ear lobe were visualized. This was proven by the demonstration of an 1:1 relationship between the fibers of the striated ear muscles at the base of the ear lobe and their supplying blood capillaries.

Histology. Rabbits were killed by overdose of pentobarbital. Ear lobes were excised at their bases and fixed in $10 \%$ phosphate buffered formalin for paraffin $(5 \mu \mathrm{m})$ or plastic $(1 \mu \mathrm{m})$ sections. Some ear lobe injection sites were excised, frozen, or freeze-dried. Whole ear sections were made perpendicular to the central ear artery. Plastic and paraffin sections were stained with hematoxylin and eosin (H \& E). Paraffin sections were also stained with periodic acid-Schiff (PAS) for basement membrane, Gomori's trichrome for collagen, and alcian blue ( $\mathrm{pH}$ 2.5) for acid mucopolysaccharides, and with a modified elastic tissueMasson trichrome stain (25). 10- $\mu \mathrm{m}$ thin frozen sections were stained enzyme-histochemically with the nonspecific esterase technique to identify macrophages (26) and immunhistochemically with rhodamine-phalloidin for F-actin in myofibroblasts (27). Mast cells in the rabbit skin were visualized in frozen sections by the toluidine blue/tetramethylene glycol ether method according to Padawer (28) and in freeze-dried sections by catecholamine fluorescence (29).

Autoradiography. To use the radioactive material sparingly, we developed a local method for $\left[{ }^{3} \mathrm{H}\right]$ thymidine labeling of the rabbit ear skin. $\left[6-{ }^{3} \mathrm{H}\right]$ thymidine with a specific activity of $185 \mathrm{GBq} / \mathrm{mM}$ (Amersham Corp., Amersham, Bucks, UK) was diluted with PBS to an activity of $7.4 \mathrm{MBq} / \mathrm{ml} .100 \mu \mathrm{l}$ of this $\left[{ }^{3} \mathrm{H}\right]$ thymidine solution were injected intradermally into the skin sites where angiotropin (or control) injections had been made $48 \mathrm{~h}$ before. After $2 \mathrm{~h}$ the animals were killed. The ear lobes were removed and immediately fixed in $10 \%$ buffered formalin.

Whole ear injection sites were serially cut perpendicular to the central ear artery into sections $\sim 2 \mathrm{~mm}$ in thickness. They were further processed by incubation with $0.1 \%$ nonlabeled thymidine in $10 \%$ buffered formalin solution for $2 \mathrm{~d}$, tap water rinsed for $8 \mathrm{~h}$, and dehydration in the autotechnicon. Paraffin and methacrylate blocks were prepared and cut into $2-$ and $1-\mu \mathrm{m}$ sections, respectively. Sections were coated with Ilford $\mathrm{K} 2$ photo emulsion heated to $45^{\circ} \mathrm{C}$ and diluted $1: 2$ in distilled water, dried, and kept refrigerated at $4^{\circ} \mathrm{C}$ for 2 wk. The slides were developed for $12 \mathrm{~min}$ in an aqueous solution containing $1.8 \%$ sodium sulfite, $0.45 \%$ Amidol (Merck), and $0.08 \%$ potassium bromide. After rinsing in water, fixation was performed with $30 \%$ sodium thiosulfate, $3 \%$ potassium metabisulfite aqueous solution. The slides were again rinsed in water, stained with Harris-eosin and mounted. 1- $\mu \mathrm{m}$ methacrylate sections were used to distinguish endothelial cells from pericytes.

Morphometry. Three whole, 1-2-mm thick ear strips were cut perpendicularly to the long ear axis out of the perfused reaction and control sites and embedded in paraffin after dehydration. 5- $\mu \mathrm{m}$ paraffin sections were stained with hematoxylin and eosin. One section per
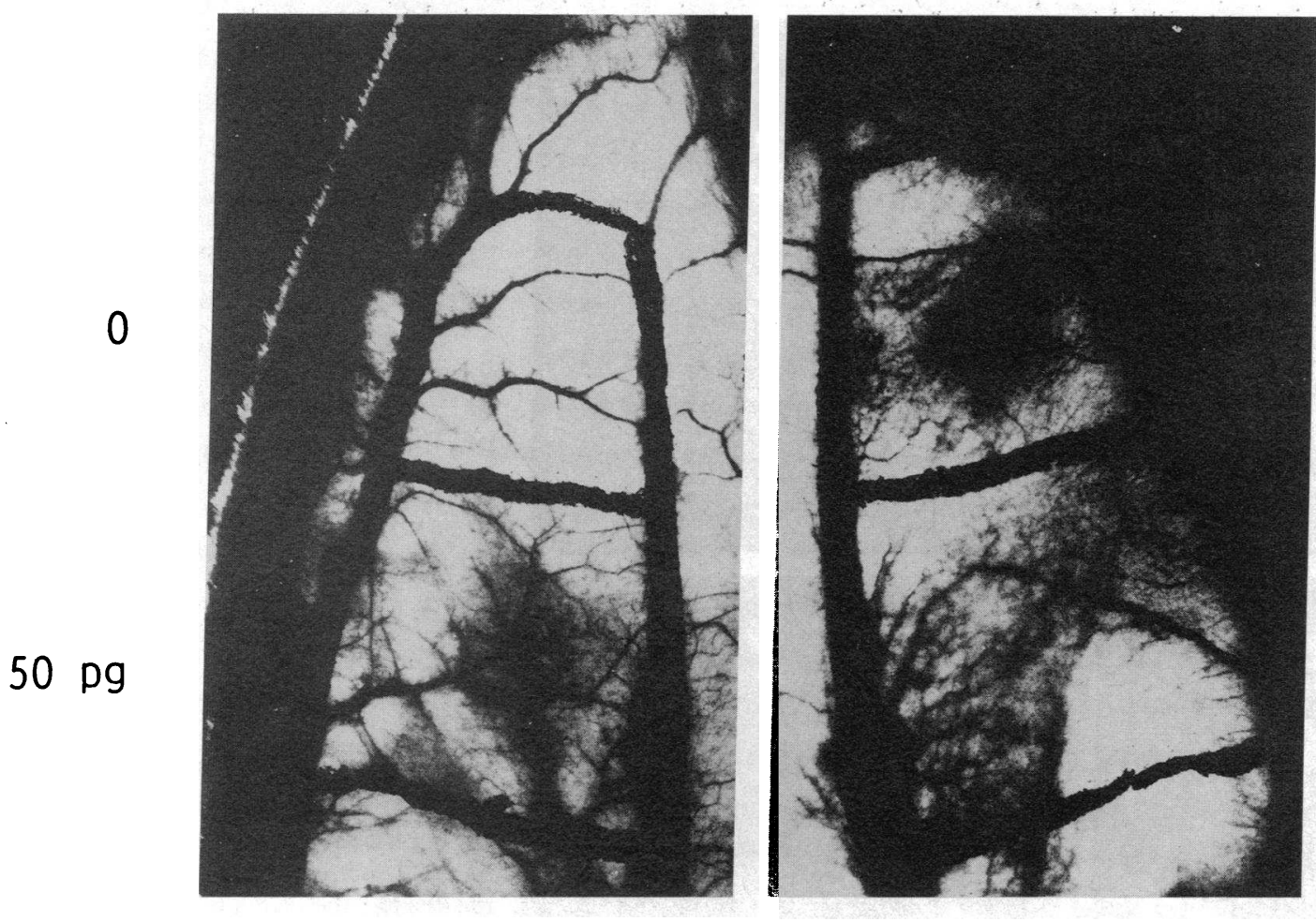

\section{$125 \mathrm{pg}$}

\section{$250 \mathrm{pg}$}

Figure 3. Dose dependence of day 2 changes of the angioarchitecture in the rabbit ear skin induced by angiotropin as seen in transmission light; $\times$ 1.5. The indicated amounts of angiotropin had been injected intradermally in 50- $\mu \mathrm{l}$ vol. 
strip was used for morphometry so that for each reaction or control area three serial histological sections of 1-2 mm apart from each other were evaluated.

The dorsal skin parts between the central artery and the lateral vein were divided into 10 unit fields by calibrating the almost linear cartilaginous bases after serial photography of the whole histologic section at magnification 16 (Fig. 1). Each unit field was further subdivided into a medial, central, and lateral part (subfield). All microvessels of one subfield per unit field were analyzed with an MOP morphometrical unit (Kontron, Zürich, Switzerland) equipped with a microcomputer. Microvessels were defined in this study as vessels without a continuous layer of smooth muscle cells, i.e., capillaries and postcapillary venules. Thus, in the first histologic section of the injection site 10 medial subfields, in the second 10 central subfields, and in the third 10 lateral subfields were processed. In each subfield the relative microvascular area, number of microvessels per square millimeter and the mean area per single vessel section were determined. The means of these parameters from the three subfields per unit field were calculated.

Laser Doppler flowmetry. Red blood cell (RBC) flux was determined with the LD 5000 capillary perfusion monitor (Medpacific Corp., Seattle, WA) digitally displayed in millivolts within a range from 0 to 2,000. The continuous flow mode was selected. A flat probe was used that could be easily fixed to the dorsal skin of the rabbit ear lobe by a double adhesive disk with a central hole. The laser beam was supplied by optical fibers in a cannula ( $1.65 \mathrm{~mm}$ diam). Light penetration depth was $\sim 1 \mathrm{~mm}$ corresponding to the whole thickness of the dorsal ear skin. For the measurements, the environmental conditions were standardized as follows. All measurements were performed at $28^{\circ} \mathrm{C}$ at a place protected from air convection. The positions of the ear lobes relative to the head and body of the animals were kept constant during a measurement and were about the same in all measurements. A series of laser Doppler experiments was also performed with the heater-probe accessory module, however, it was found to be of no advantage compared to the standard measurements without that device. The animals were anesthetized using the intramuscular xylazine/ ketamine regimen superimposed by halothane/oxygen supplied with a semi-open face mask system. Under these conditions, ear skin micrevascular (RBC) flux was quite stable after 15-20 min. Three laser Doppler measurements were performed at each probe position. Each measurement was recorded for at least $1 \mathrm{~min}$, showing an almost linear record with only short-term fluctuations. The means of all three measurements were used for comparisons. In a few cases, long period fluctuations occurred. Under these circumstances the whole series of measurements was discarded and repeated.

The probe was shifted along a line $\sim 1 \mathrm{~cm}$ lateral from and parallel to the central ear artery beginning at the ear tip and moving towards the base at $\sim 3$ - or 5-mm steps avoiding larger vessels. Measurements were always done on the ear lobe treated with angiotropin and on the homologous sites of the contralateral ear lobe, which received a control injection in the same session.

\section{Results}

Macroscopic effects. The macroscopic changes in the rabbit ear skin induced by intradermal angiotropin have been described in detail elsewhere (30). In brief, the cutaneous papule produced by the standard $50-\mu l$ bolus of intradermal angiotropin $(250 \mathrm{pg})$ or control solution disappeared several min after injection. The site which received angiotropin remained unremarkable for 2-4 h.

The subsequent changes in the angioarchitecture seen coarsely using transmission light were dose dependent and fol-
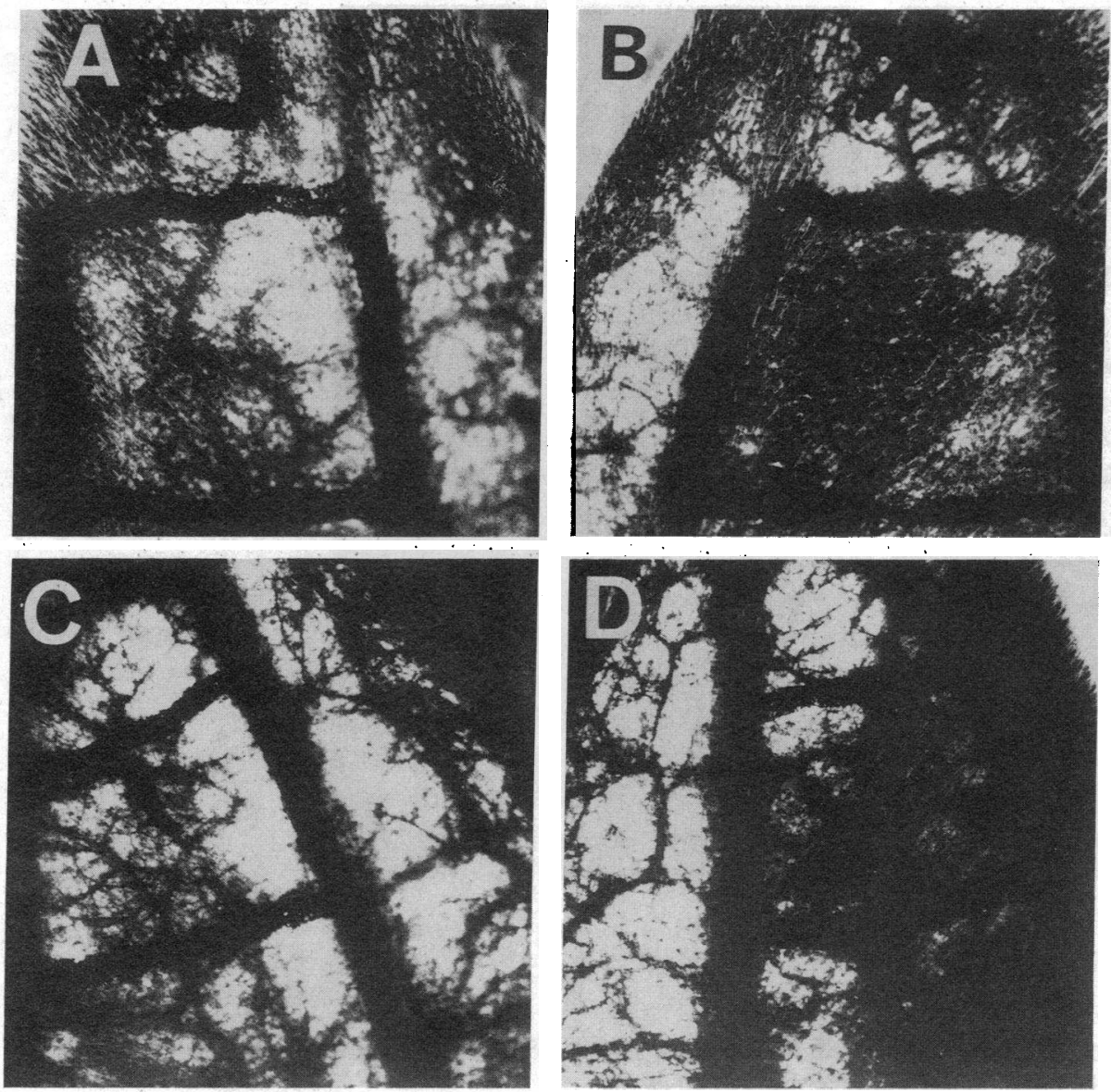

Figure 4. Homologous sites of rabbit ear lobes perfused with dextran 60 and india ink to demonstrate the vascular patterns 2 $\mathrm{d}(B)$ and $8 \mathrm{~d}(D)$ after intradermal injection of $500 \mathrm{pg}$ of angiotropin in $50 \mu \mathrm{l}$ solution. The corresponding controls at day 2 $(A)$ and day $8(C)$ received the same buffer and carrier solution without angiotropin; $\times 2$. The injections were made into the centers of the outlined areas. 
lowed defined dynamics. Initially, the site of injection could be discriminated from the surrounding skin areas by a slight redness at the center and a blurring of some vessel contours at the periphery. Within $24 \mathrm{~h}$, these effects markedly increased. After $48 \mathrm{~h}$, blood vessel contours could be outlined again. They appeared extremely dilated. Numerous tortuous and irregular blood vessels could be observed (Fig. 2). The major draining venes were markedly congested including the parts far beyond the injection sites. Fig. 3 demonstrates the dose dependency of the day 2 effects by the macroscopic appearance of the angioarchitecture at the injection sites of different concentrations of angiotropin in the same animal. Within the next days vascular prominence gradually decreased and from day 6 on, the former area of angiotropin injection was slightly reddish compared to the surrounding skin. No change in blood vessel appearance was ever noted at skin sites of the control injections.

The angiotropin-induced macroscopic changes in angioarchitecture at day 2 and day 8 visualized after temperature and pressure controlled whole blood replacement by dextran 60 and subsequent perfusion with filtered india ink are shown in Fig. 4. Vascular filling at the site of angiotropin injection was so intense that blood vessels could not be discriminated macroscopically. Both day 2 and day 8 reactions showed, however, a marked increase in the overall vascular volume at the site of angiotropin injection compared with the homologous skin sites of the contralateral ear lobe which received the control injections that did not change the angioarchitecture.

In animals that showed resting hair follicles of the ear lobe at the time of angiotropin injection, a well-circumscribed area of moderate to abundant growth of long hair was present in the injection site around day 10 . Adjacent skin regions remained free of hair for up to 6 wk or longer.

Microscopic vascular changes. The histological sections of the perfused skin at day 2 after the intradermal injection of angiotropin showed dilation of all blood vessel types except the arteries. Capillaries and postcapillary venules lined by endothelial cells and pericytes only were extremely engorged and resembled sinusoidal blood channels with diameters exceeding $100 \mu \mathrm{m}$ (Fig. $5 \mathrm{~B}$ ). The shape of most of the blood vessel sections filled with india ink was irregular and bulged out in contrast to the almost round or ellipsoid shapes of most of the vessel sections from the controls (Fig. $5 \mathrm{~A}$ ). There was, however, no evidence for significant india ink extravasations at that time.

At day 8 after angiotropin treatment (Fig. $5 C$ ) the contours of most of the vessels were not much different from the controls. However, the number of microvessel sections in the treated skin appeared to be increased compared with the controls, especially in the perifollicular and perichondrial vascular plexus.

To quantify the vascular changes induced by angiotropin, a morphometrical analysis of day 2 and day 8 microvessels without continuous muscle layer (capillaries and postcapillary venules) in the treated and control skin sites was performed. The results are compiled in Figs. 6 and 7 and in Table I.

According to the qualitative impression from the macroscopic and microscopic observations the relative microvascular volume was significantly increased at the skin sites treated with $500 \mathrm{pg}$ of angiotropin compared with the untreated neighborhood or with skin areas receiving control injections. The increase of microvascular blood volume on day 2 was mainly caused by the enlargement of the individual vessels,
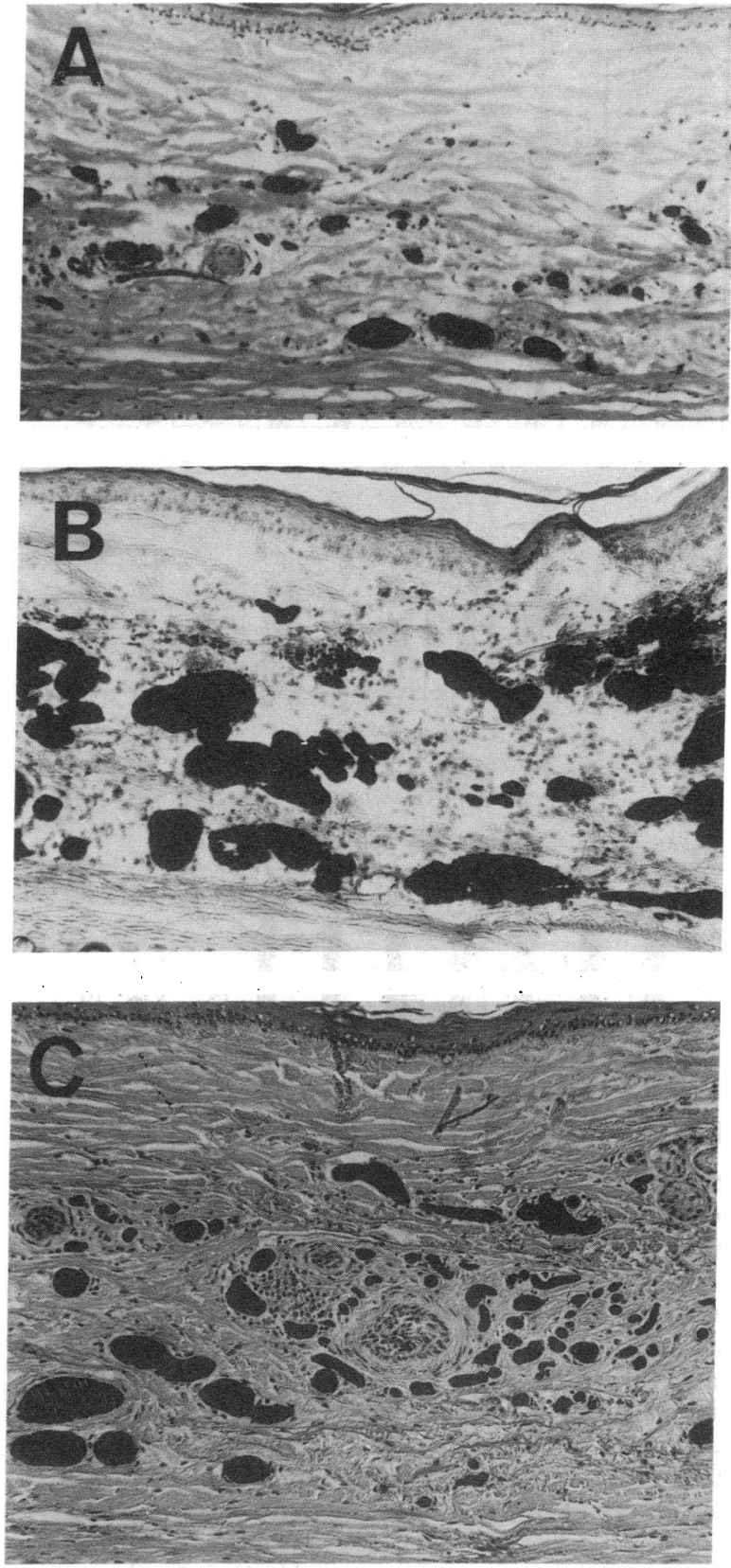

Figure 5. Histologic sections of homologous dorsal skin parts of rabbit ear lobes perfused with dextran 60 and india ink to show microvascular changes induced by intradermal injections of angiotropin. (A) Injection of $50 \mu \mathrm{l}$ of buffer and carrier solution without angiotropin (control). (B) $2 \mathrm{~d}$ after injection of $50 \mu \mathrm{l}$ solution containing 500 $\mathrm{pg}$ of angiotropin. $(C) 8 \mathrm{~d}$ after injection of $50 \mu \mathrm{l}$ solution containing $500 \mathrm{pg}$ of angiotropin. Note also the epidermal hyperplasia and thickening of the dermis following the injection of angiotropin; $\times 75$.

whereas the relative number of microvessels was not significantly changed at that time. At day 8 , however, the mean microvessel diameters in the treated and control skin areas were not significantly different and the increase in the relative vascular volume in the treated skin was due to the increased number of microvessels per unit tissue volume. The overall angiogenic effect of angiotropin was represented by an increase in the relative number of microvessels as well as by an increased thickness of the vascularized dermis. 

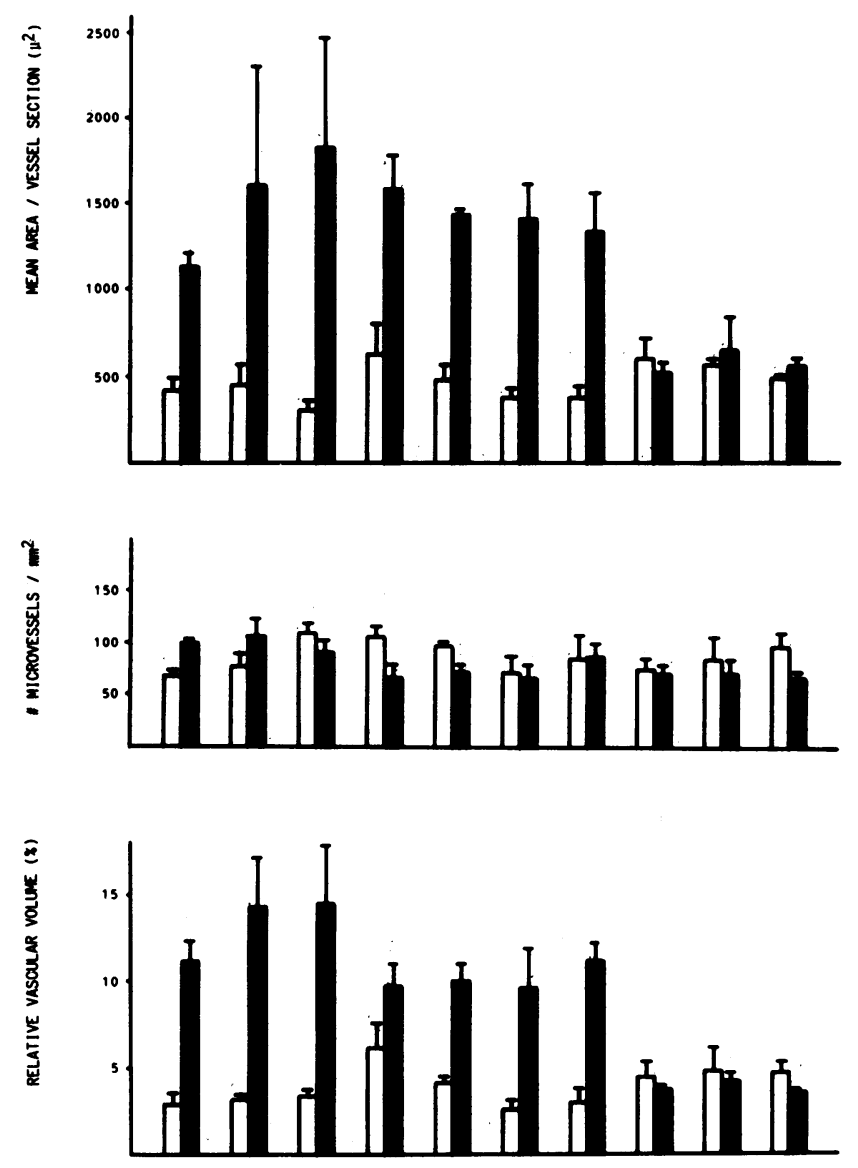

$\begin{array}{llllllllllll}\text { A } & \text { F1 } & \text { F2 } & \text { F3 } & \text { F4 } & \text { F5 } & \text { F6 } & \text { F7 } & \text { F8 } & \text { F9 } & \text { Fio } & \mathbf{V}\end{array}$

Figure 6. Histogram demonstrating the quantified changes of the blood vessels without continuous muscle layer in the skin of a rabbit's ear lobe $2 \mathrm{~d}$ after intradermal injection of $500 \mathrm{pg}$ of angiotropin in $50 \mu$ solution. The dorsal skin parts between central artery $(A)$ and lateral vein $(V)$ in transverse whole ear sections were subdivided into 10 unit fields ( $F 1$ to $F 10$ ). Mean values \pm SD of three serial sections are shown. Black bars represent the skin site treated with angiotropin, the white bars correspond to the homologous site of the contralateral ear lobe, which received an intradermal injection of the buffer and carrier solution without angiotropin. The F4 unit fields contained the centers of injections. The skin papule which arose transiently from the intradermal injection extended medially to the F1 unit fields and laterally to the F7 unit fields. Vascular changes are confined to that area.

Changes in local microcirculation. Laser Doppler flowmetry is a valid method for the determination of alterations in the microvascular RBC flux in our animal model as the penetration depth of the laser beam corresponds to the thickness of the dorsal skin of the rabbit ear lobe where all the vascular changes occurred.

Fig. 8 shows the daily changes in RBC flux after injection of $500 \mathrm{pg}$ of angiotropin at the treated and control skin sites in a representative experiment. Peak values were reached on day 1. Thereafter, there was a continuous decrease of the RBC flux until day 6. Constant RBC fluxes which were still higher than those observed in the control ear lobe were then maintained until day 10 , which was the last day of the observation period.
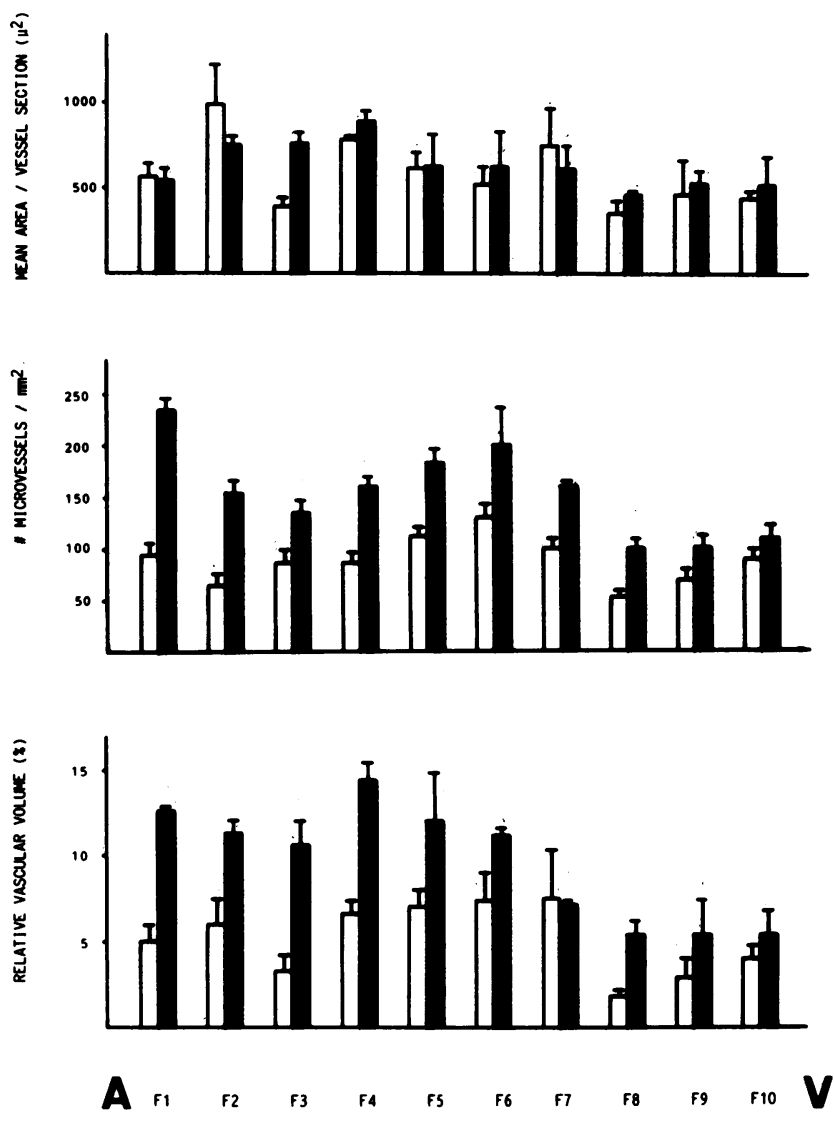

Figure 7. Histogram showing the quantified changes of the blood vessels without continuous muscle layer in the skin of a rabbit's ear lobe 8 days after intradermal injection of $500 \mathrm{pg}$ of angiotropin. Details are in the legend of Fig. 6. The centers of injections were within the F4 and F5 unit fields, the injection papule extended medially to the F1 unit fields and laterally to the F8 unit fields.

Table I. Morphometrical Evaluation of Changes in the Angioarchitecture of Rabbit Skin Induced by Intradermally Injected Angiotropin (500 pg)*

\begin{tabular}{lccc}
\hline & $\begin{array}{c}\text { Relative vascular } \\
\text { volume }\end{array}$ & $\begin{array}{c}\text { No. of } \\
\text { microvessels } \\
\text { per } \mathrm{mm}^{2}\end{array}$ & $\begin{array}{c}\text { Mean area per } \\
\text { single vessel } \\
\text { section }\end{array}$ \\
\hline & $\%$ & & $\mu m^{2}$ \\
Control $(n=14)$ & $4.6 \pm 0.4$ & $88 \pm 6$ & $521 \pm 36$ \\
Day 2 reaction $(n=7)$ & $(P=0.02)$ & $(\mathrm{NS})$ & $(P=0.02)$ \\
& $10.4 \pm 1.1$ & $183 \pm 13$ & $592 \pm 70$ \\
Day 8 reaction $(n=7)$ & $(P=0.02)$ & $(P=0.02)$ & $(\mathrm{NS})$ \\
\hline
\end{tabular}

* Morphometrical analysis was done as described in Methods. Instead of the whole ear sections only three serial F4 unit fields in the center of the site of intradermal injection were analyzed in each animal. Perimetry of all microvessels without continuous muscle layer of one subfield per F4 unit field was performed. Mean values \pm SEM of three serial F4 unit fields of 7, respectively, 14 rabbits as well as statistical evaluation by the signed rank test are indicated. 


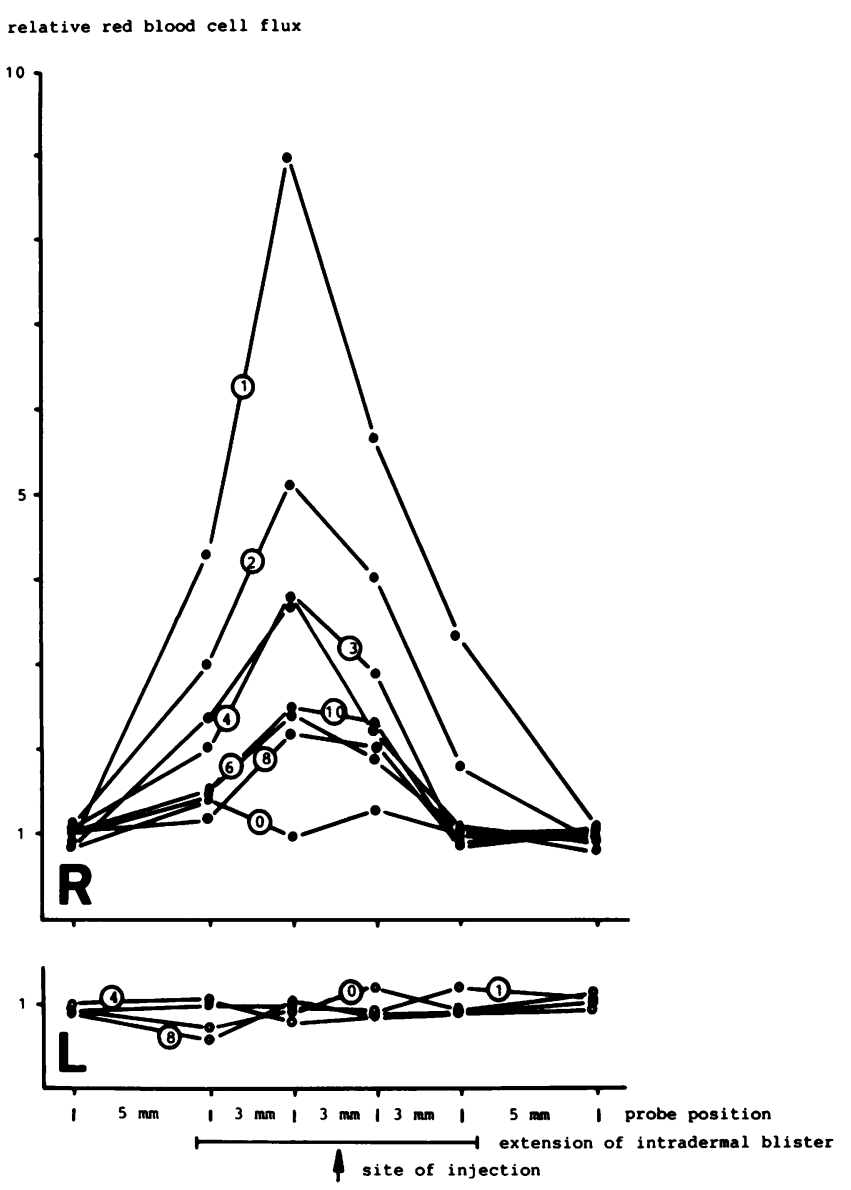

Figure 8. Daily changes of RBC flux (in relative units) in the ear lobe skin of a rabbit induced by angiotropin. $500 \mathrm{pg}$ of angiotropin were injected in $50 \mu$ l solution into the right ear lobe $(R)$. The homologous site of the left ear lobe $(L)$ received $50 \mu \mathrm{l}$ of buffer and carrier without angiotropin. The mean values of the RBC flux determined at two points proximal and distal from the initial intradermal blister of the injected solution were used as reference for the calculation of the relative values. The encircled numbers indicate the time of laser Doppler flowmetry in days after injection.

The mean values of the relative RBC fluxes determined in 6 animals at two different times were consistent with these results and prove statistical significance (Fig. 9).

The dose dependency of the angiotropin-induced changes in angioarchitecture shown qualitatively in Fig. 2 has also been quantified by means of laser Doppler flowmetry (Fig. 10). In addition to the early (day 2) effects, dose dependency could also be demonstrated for the late (day 8) changes of the microcirculation.

Endothelial cell reactions. $24 \mathrm{~h}$ after intradermal injection of angiotropin (Fig. $11 \mathrm{~B}$ ) the endothelial cells and pericytes of capillaries and postcapillary venules showed enlarged oval vesicular nuclei, prominent nucleoli, and an increase in the slightly basophilic cytoplasm. Intramural cell to cell distances were increased compared to unstimulated controls. At this stage there was no evidence of endothelial cell necrosis, vascular occlusion or thrombosis.

At $48 \mathrm{~h}$ after injection of $250 \mathrm{pg}$ of angiotropin an autoradiographic study was performed. The still prominent endothe-

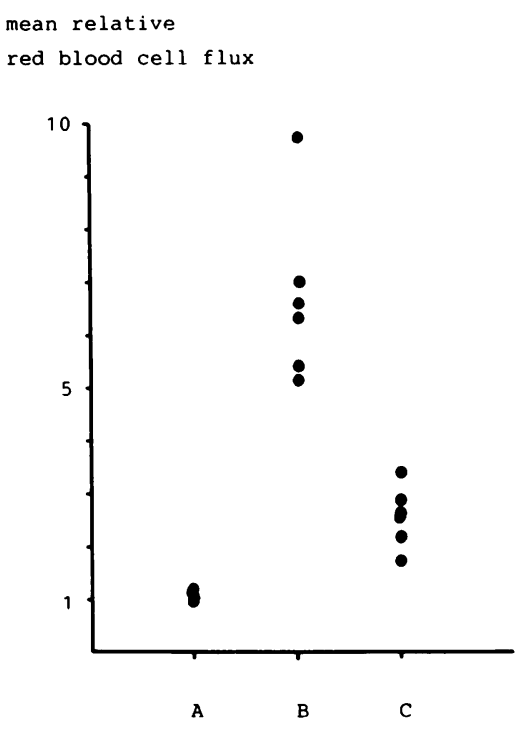

Figure 9. Mean RBC flux (in relative units) in rabbit ear skin sites which were treated with angiotropin. Details are given in the legend of Fig. 8. Each point represents the mean of four laser Doppler measurements within the injection site of one animal related to the RBC flux of two reference points beyond the site of injection. $(A)$ Control, before injection of angiotropin. (B) $2 \mathrm{~d}$ after intradermal injection of 500 $\mathrm{pg}$ of angiotropin in 50 $\mu$ l solution. $(C) 8 \mathrm{~d}$ after intradermal injection of $500 \mathrm{pg}$ of angiotropin in $50 \mu$ l solution. Level of significance (signed rank test) $P$ $=0.036$ for day 2 and day 8 changes $(n=6)$.

lial cells and pericytes of the capillaries and postcapillary venules exhibited strong $\left[{ }^{3} \mathrm{H}\right]$ thymidine labeling that was increased 23-fold and 5-fold, respectively, when compared to vessels of control tissue (Table II, Fig. $12 \mathrm{D}$ ). No significant labelling was observed in arteries, arterioles and the larger venous vessels. By day 3 , clusters of closely spaced new capillaries and/or sprouts appeared in dermal areas that were closely associated with larger existing blood vessels (Fig. $11 C$ ). These structures showed plump endothelial cells with oval nuclei and clear lumina. The pericapillary stromal matrix was amorphous, loose connective tissue.

At day 4 there was histological evidence of disintegration of some of the microvessels which showed swollen endothelial cells and pericytes with nuclear pyknosis, karyolysis, and cytoplasmic vacuoles. Some vessel walls disclosed focal effacement and structural dissolution with intramural and perivascular

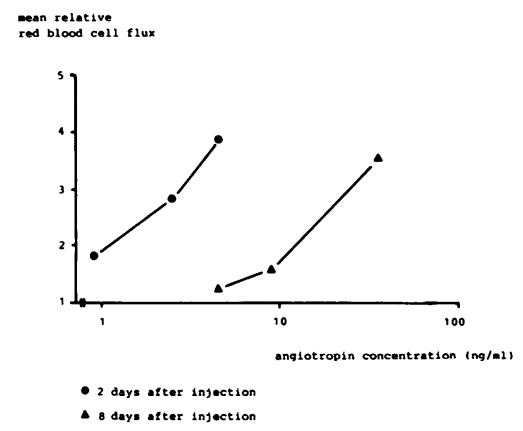

Figure 10. Dose dependence of the changes of the mean RBC flux in the rabbit ear skin induced by angiotropin. The mean values of four measurements within each site of injection are given. The points represent the dose dependence of day 2 alterations in one rabbit; the triangles indicate the dose dependence of day 8 changes in another rabbit. 

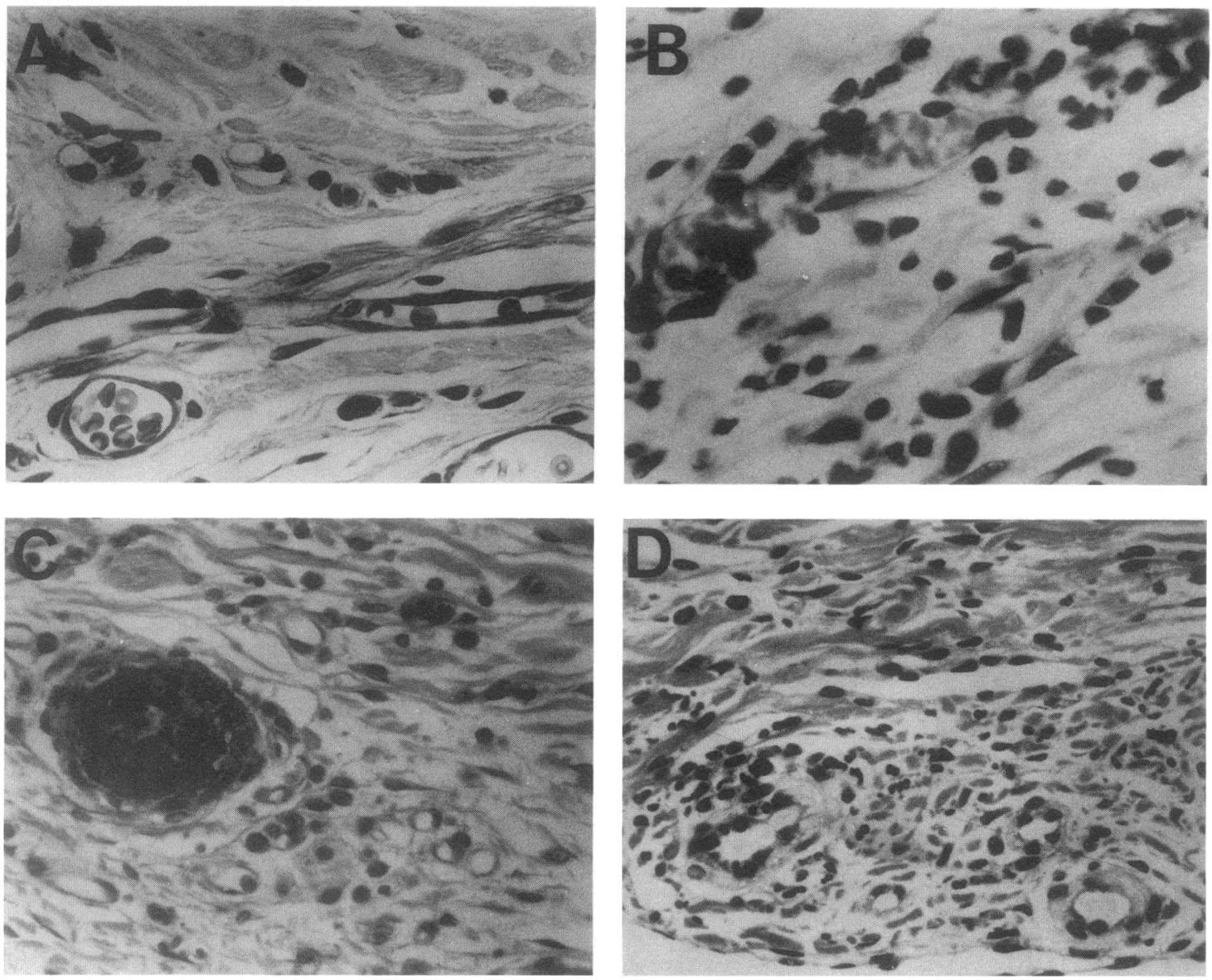

Figure 11. Morphological changes of the endothelial cells of capillaries and postcapillary venules in the rabbit ear skin induced by intradermal injection of angiotropin. $(A)$ Control: several sections of capillaries and small venules showing normal flat endothelial cells and pericytes. (B) Activated endothelial cells and pericytes $24 \mathrm{~h}$ after intradermal injection of $125 \mathrm{pg}$ of angiotropin in $50 \mu \mathrm{l}$ solution. Some

infiltration of large vacuolated macrophages admixed with lymphocytes, plasma cells, eosinophils, occasional PMN leukocytes and nuclear dust (Fig. $11 \mathrm{D}$ ). Degenerating vessels

Table II. $\left[{ }^{3} \mathrm{H}\right]$ Thymidine Labeling of Various Cell Types in the Rabbit Ear Skin $2 d$ after Intradermal Injection of Angiotropin

\begin{tabular}{lcccc}
\hline & $\begin{array}{c}\text { Epidermal } \\
\text { cells* }\end{array}$ & $\begin{array}{c}\text { Endothelial } \\
\text { cells }\end{array}$ & Pericytes & $\begin{array}{c}\text { Stromal } \\
\text { cells }\end{array}$ \\
\hline Control $(n=4)$ & $56.8 \pm 12.8$ & $0.3 \pm 0.4$ & $0.6 \pm 0.3$ & $3.3 \pm 1.1$ \\
Angiotropin $(n=5)$ & $259.7 \pm 12.8$ & $7.0 \pm 1.5$ & $3.1 \pm 0.9$ & $9.7 \pm 0.9$
\end{tabular}

$250 \mathrm{pg}$ of angiotropin in $50 \mu \mathrm{l}$ isotonic solution was injected intradermally; control injections containing the same solution without angiotropin were carried out at the corresponding sites of the contralateral ear lobes.

* The number of labeled epidermal cells was determined by counting 1,000 epidermal cells in each animal.

F For all other cell types the mean number of labeled cells per high power field $(400 \times)$ based on the countings of 30 random high power fields per animal are indicated. Mean values \pm SD are given. Statistical evaluation using the signed rank test revealed $P=0.02$ for the increase of labeled cells of all four types.
PMN leukocytes have emigrated into the stroma. $(C)$ Numerous smallest capillary-like sections without erythrocyte filling $3 \mathrm{~d}$ after injection of $250 \mathrm{pg}$ of angiotropin. (D) Degenerating vessels showing endothelial cell and pericyte swelling surrounded by macrophages 4 $\mathrm{d}$ after injection of $250 \mathrm{pg}$ of angiotropin. $\mathrm{H} \& \mathrm{E}$ stained paraffin sections; $A, B \times 630 ; C, D \times 400$.

appeared to be replaced by cord-like arrangements of vacuolated macrophages (Fig. $16 \mathrm{~B}$ ). Focal deposits of intraluminal fibrin were seen in some degenerating vessels. The involutional changes subsided gradually and by day 8 blood vessels did not differ microscopically from those of controls or untreated skin. Despite the involutional changes of some vessels there was still a significant net increase in the amount of microvessels without a continuous muscle layer at day 8 as shown by the morphometrical analysis.

Epidermal changes. Marked histological changes were observed in the epidermis after intradermal angiotropin. The in duced changes were confined to the basal layer in the first several days (Fig. 13) and consisted of: (a) prominent nuclear hyperchromasia (day 1-4), (b) moderate to abundant mitotic activity (day $1-2),(c)$ increased $\left[{ }^{3} \mathrm{H}\right]$ thymidine incorporation (day 2), (d) pseudostratification of the basal layer (day 2-4), and $(e)$ deformation of the underlying basement membrane (day 1-4). Mitotic figures were reduced by day 2 and were uncommon by day 3 . From day $2-4$, the basal layer was intensely crowded with increased numbers of homogenous hyperchromatic basal cells that formed a thick basal zone that comprised $1 / 3$ to $1 / 2$ the total thickness of the entire epidermis. Basal cell nuclei were shifted vertically into three to four pseudostratified layers. The hypercellularity appeared to produce 

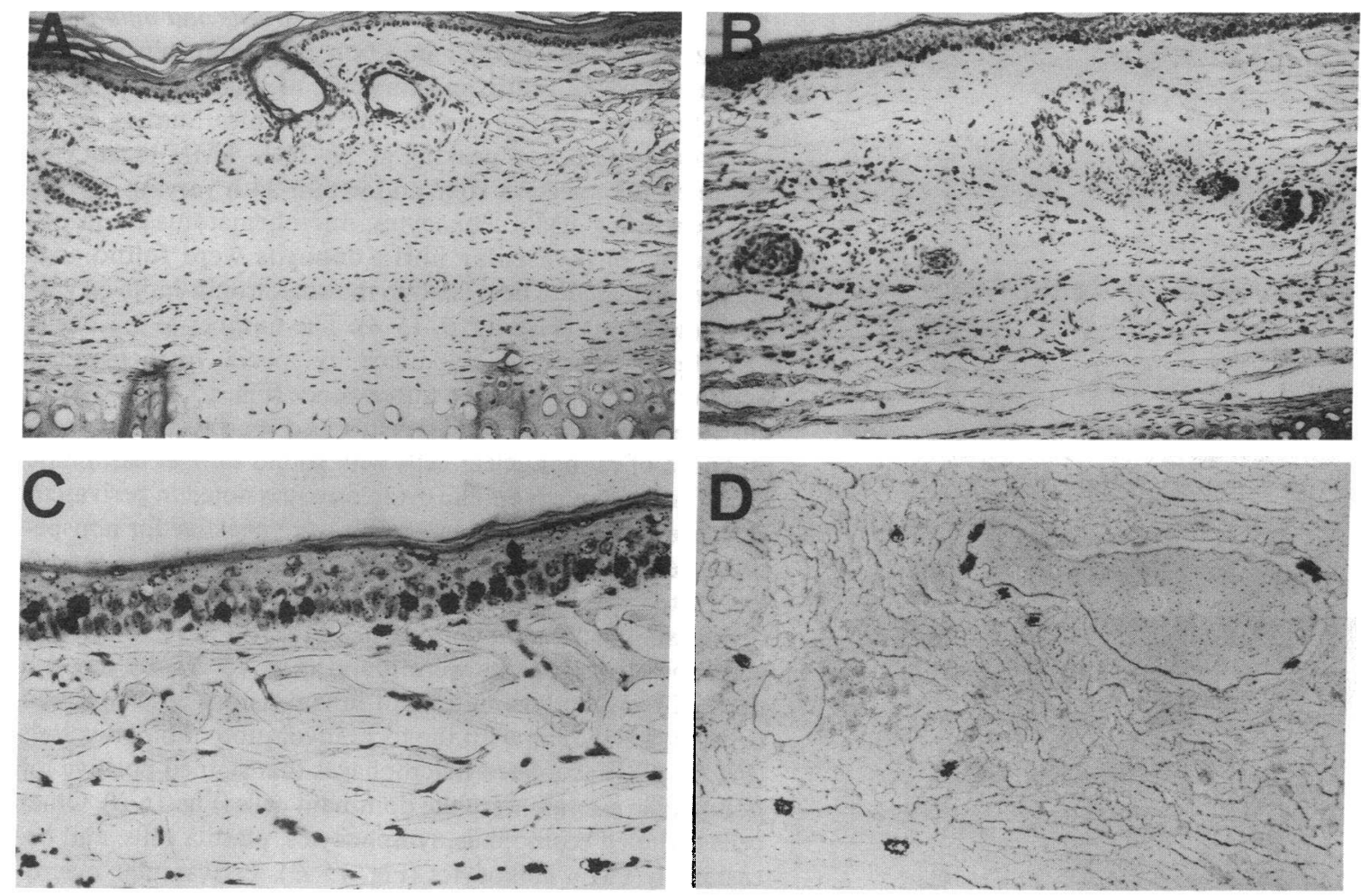

Figure 12. Autoradiography with $\left[{ }^{3} \mathrm{H}\right]$ thymidine $48 \mathrm{~h}$ after intrader$\mathrm{mal}$ injection of $250 \mathrm{pg}$ of angiotropin in $50 \mu \mathrm{l}$ solution into the dorsal skin of rabbit ears exhibiting profound labeling of different cell types $(B)$. In addition to the excessive epidermal labeling $(C)$, higher magnification of plastic sections demonstrates intensive labeling of the endothelial cells and pericytes of the engorged capillaries and postcapillary venules as well as stromal cells $(D)$. As control the ho- mologous skin site of the contralateral ear $48 \mathrm{~h}$ after the intradermal injection of $50 \mu$ l of buffer and carrier without angiotropin is shown $(A)$. There is only some labeling of epidermal and hair follicle cells. A few stromal cells also show incorporation of radioactivity. Endothelial cell and pericyte labeling was very rarely found. $(A, B)$ paraffin sections; $\times 100,(C)$ paraffin section; $\times 250,(D)$ plastic section; $\times 630$. All sections were stained with Harris-eosin. downward pressure changes which distorted and yielded the scallop configuration of the basement membrane. However, marked alterations of the epidermal basement membranes were already found in PAS stained histologic sections before basal layer hypercellularity became prominent (Fig. 14). Therefore, basement layer changes may not only be explained by epidermal proliferation but may precede proliferation.

Autoradiography at day 2 revealed a fourfold increase in $\left[{ }^{3} \mathrm{H}\right]$ thymidine labeling of the basal layer (Table II, Fig. 12, $A$ and $B$ ). Some thymidine label was found in the first basal stratum, however, most of the label was present in the second or higher basal strata (Fig. $12 \mathrm{C}$ ). Regression of basal layer changes was evident after day 4, and by day 6 the basal layer appeared normal while the strata spinosum and granulosum showed prominence with increased numbers of large mature keratinocytes. The prominence of the upper epidermis approached normality by day 12 . These changes were not seen in epidermis distant to angiotropin injection sites or in the sites of injected control substances.

Epidermal thickness was selected as an indicator of epidermal hyperplasia. Serial epidermal thickness measurements show a dose-dependent relationship between epidermal hyperplasia and the concentration of injected angiotropin within the concentration range of 50 to $5000 \mathrm{pg}$ in $50-\mu l$ isotonic aliquots (Table III). The angiotropin-induced epidermal changes were interpreted as transient but rapid stimulation of DNA-synthesis and cell division of the basal layer from day
$0-2$, hypercellularity of the basal zone from day $2-4$, and migration/maturation of keratinocytes in the upper epidermis from day 4-10.

Effects on dermal fibroblasts, extracellular matrix and hair follicles. Stromal changes induced by intradermal injection of angiotropin were found throughout the dermis, however they were more prominent in the deep reticular dermis adjacent to the perichondrium. Day 2 autoradiography disclosed an increased $\left[{ }^{3} \mathrm{H}\right]$ thymidine labeling of stromal cells that were threefold greater when $250 \mathrm{pg}$ of angiotropin were injected than in controls (Table II). Increased numbers of large fusiform fibroblasts with oval vesicular nuclei and basophilic cytoplasm were present by day 3 (Fig. $15 \mathrm{D}$ ) along with occasional stromal mitoses. From day 2-8, multiple pockets of loose connective tissue were found in the mid-reticular dermis in areas associated with blood vessels that were undergoing proliferative changes and neovascularization. This loose matrix consisted of thin short strands of widely spaced collagen fibers with modest numbers of fibroblastoid and/or primitive mesenchymal cells. At day 4 macrophages and other inflammatory cells infiltrated this loose matrix during the phase of vascular involution. By day 8 the dermal stromal cells returned to control morphology, however, their number appeared to be increased. The dermis remained somewhat thickened at day 12 although no specific histological alteration was evident. The normal basketweave pattern of dermal collagen remained intact. Deposition of new extracellular matrix was not detected 

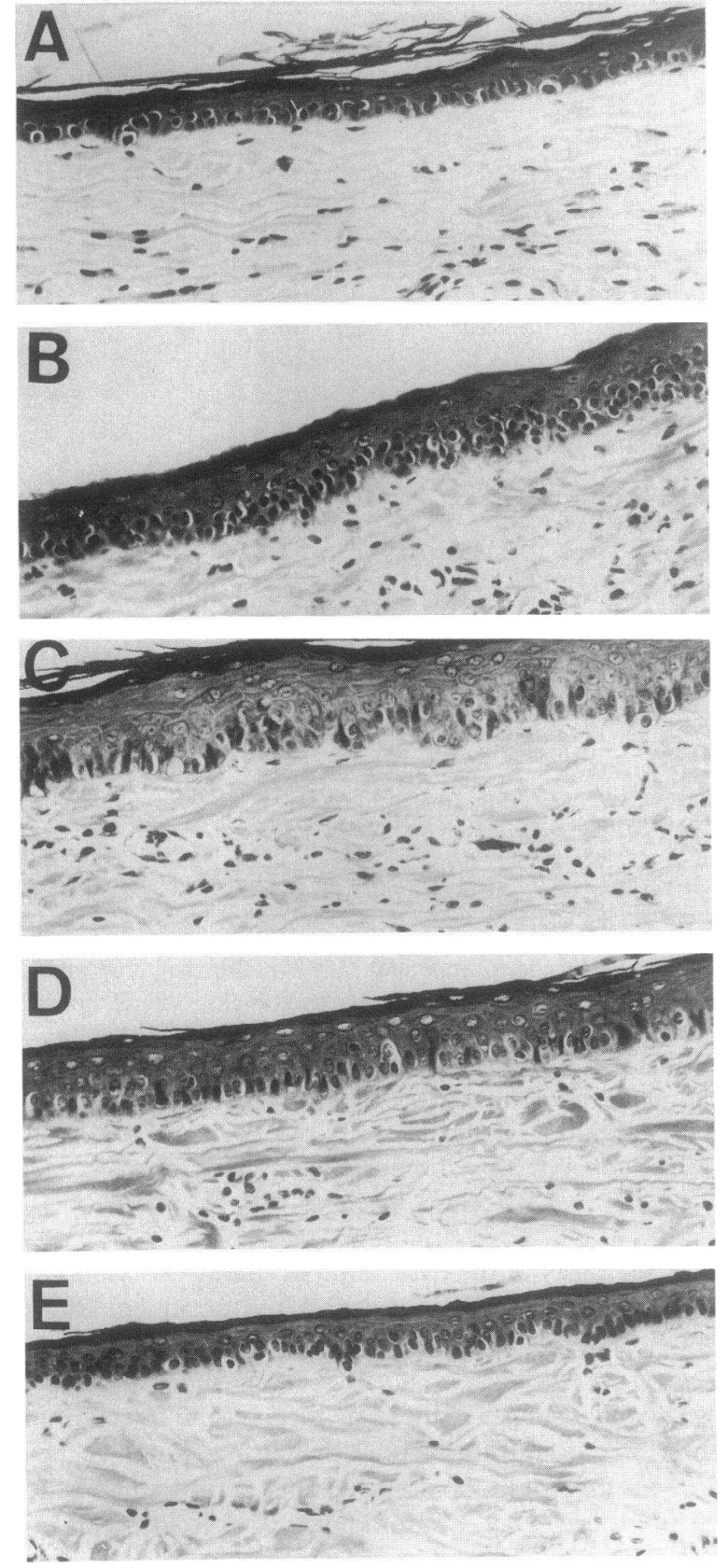

Figure 13. Proliferative epidermal changes after intradermal injection of $250 \mathrm{pg}$ of angiotropin in $50 \mu \mathrm{l}$ of buffer and carrier solution into the dorsal skin of rabbit ear lobes. $\mathrm{H} \& \mathrm{E}$ stained paraffin sections; $\times 250$. $(A)$ control: normal epidermis; $(B)$ day 2: basal layer shows nuclear hyperchromasia, hypercellularity and pseudostratification; $(C)$ day 3: thick basal layer zone with pseudostratification; $(D)$ day 6: normal basal layer and prominent stratum spinosum; $(E)$ day 12: near normal epidermis.

by polarized light microscopy, Gomori's trichrome stain for collagen and the alcian blue method for acid mucopolysaccharides. Rhodamine phalloidin immunhistochemistry did not show myofibroblasts. Granulation tissue, fibrosis or skin contracture were not seen. The histological features of anagenphase hair follicles were present in the skin sites into which angiotropin was injected whenever the control skin contained resting hair follicles.
Dynamics of resident connective tissue cells and inflammatory cells. The intradermal injection of angiotropin was accompanied by an influx and turnover of inflammatory cells, which followed relatively predictable dynamics. Starting about $2 \mathrm{~h}$ postinjection and peaking at 12-24 h, PMN leukocytes infiltrated the injection zone and within $24 \mathrm{~h}$ varying degrees of degenerating PMN leukocytes, microhematomas, and occasionally extravascular fibrin deposits were found. All changes appeared to be related to the angiotropin-induced vascular alterations (Figs. $11 \mathrm{~B}, 15 \mathrm{~A}$ ). The number of mast cells was also increased as evidenced by special histochemical staining and catecholamine fluorescence (Fig. 15 B). By day 2, the number of PMN leukocytes dropped sharply and an accumulation of mononuclear cells with round to oval basophilic nuclei and pale eosinophilic cytoplasm was noted in perivascular spaces. These mononuclear cells were negative for nonspecific esterase and were thought to represent primitive, undifferentiated mesenchymal cells (Figs. $15 \mathrm{C}, 16 \mathrm{~A}$ ). On day 3, fibroblastoid cells were dominant, PMN leukocytes were rare and more macrophages were found (Fig. $15 \mathrm{D}$ ). By day 4 a marked perivascular infiltrate of inflammatory cells appeared in direct association with the focal involution of blood vessels (Fig. $11 D$ ). Vacuolated macrophages that stained positive for nonspecific esterase were the dominant cells (Fig. $16 \mathrm{~B}$ ). Other cells included eosinophils, lymphocytes, plasma cells, and occasionally PMN leukocytes (Fig. $15 E$ ). Perivascular macrophages persisted until the focal vascular involution was complete. Inflammatory cells were rare from day 8 on.

Control studies. Rabbit ear lobes were injected with a variety of control substances and the injection sites were studied daily to day 10 for macroscopic and microscopic alterations. The serum-free medium (BM-86 Wissler), which was used in the porcine monocyte cultures and which contained 91 components, produced no significant tissue reaction after intradermal injection. Concanavalin $\mathrm{A}$, when injected in the bioactive concentrations of angiotropin, did not show any effects. However, when the lectin was injected in concentrations used for monocyte activation in vitro, an immediate hyperemia occurred followed by an inflammatory reaction that persisted for $24 \mathrm{~h}$. However, no significant neovascularization was noted. $30 \mu \mathrm{M}(3 \mathrm{mg} / \mathrm{ml})$ of concanavalin A produced a very strong local inflammatory reaction, skin necrosis and weak neovascularization. As can be seen from Table IV, substances causing temporary vasodilation and other features of acute inflammation without skin damage did not produce an angiogenic response in the skin model chosen. The degree of PMN leukocyte infiltration did not correlate with the angiogenic response.

Except for angiotropin, macroscopically detectable neovascularization was always associated with macroscopic skin necrosis. Angiotropin-induced skin reactions were not inhibited by coinjection of dexamethasone in concentrations that are effective clinically in the suppression of local inflammation. Dexamethsone can significantly inhibit wound healing when administered focally for more than $10 \mathrm{~d}$ in a biodegradable therapeutic system (31). Long-term dexamethasone in combination with single bolus angiotropin did not inhibit tissue proliferation. In contrast, it seemed to potentiate the angiotropininduced neovascularization.

\section{Discussion}

The intradermal injection of $<0.5 \mathrm{ng}$ of a highly purified monocyte-derived angiogenic substance (angiotropin) into the 

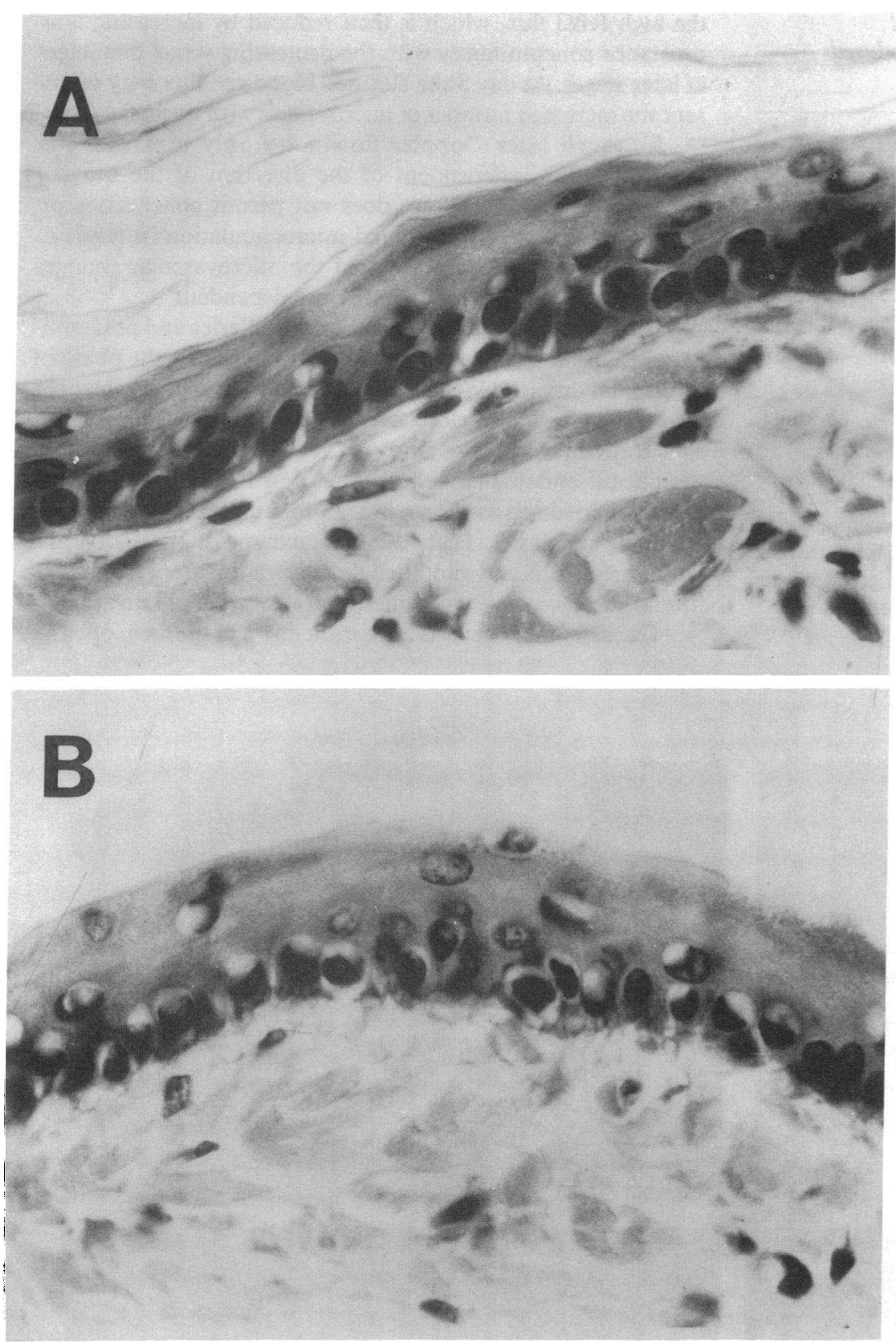

Figure 14. Early changes in epidermal basement membrane within $24 \mathrm{~h}$ after the intradermal injection of $125 \mathrm{pg}$ of angiotropin in $50 \mu \mathrm{l}$ solution into the dorsal skin of rabbit ear lobes. PAS stained paraffin sections; $\times 630$. $(A)$ Control: smooth linear basement membrane, $(B)$ distortion and early scallop configuration of the basement membrane. dorsal skin of rabbit ear lobes produced profound changes in the angioarchitecture. By use of a temperature and pressure controlled perfusion technique with dextran 60 for whole blood replacement and subsequent perfusion with filtered india ink, all blood vessels could be detected for histomorphometrical analysis. As a result, the vascular changes induced by angiotropin can be summarized in two stages that can be observed at days 2 and 8 after injection. During the early phase all blood vessels, except arteries, are dilated. Capillaries and postcapillary venules are extremely enlarged forming irregularly shaped sinusoidal blood channels. Vascular dilation respectively engorgement induced by angiotropin begins about 2 $\mathrm{h}$ after injection and lasts for more than $2 \mathrm{~d}$. Angiotropin strikingly differs in this respect from known vasodilators like histamin or prostaglandin $E_{2}$, which produce much shorter effects with earlier onset. Even the long acting vasodilator cal- citonin gene-related peptide does not lead to local hyperemia of comparable duration when injected into rabbit skin (32). The vasodilating effect of the latter substance also starts much earlier.

In the late phase after angiotropin injection blood vessels appear to be reduced to almost normal shape and size but the number of microvessels without a smooth muscle layer is significantly increased compared with the controls.

The morphological results were confirmed by the investigation of the changes in hemodynamics induced by angiotropin with laser Doppler flowmetry. Both day 2 and day 8 vascular changes lead to an increased red blood cell flux. However, day 2 flux was much higher than day $8 \mathrm{RBC}$ flux although the relative microvascular volume at day 8 was only slightly less than that of day 2. Obviously, the sinusoidally enlarged microvessels with lowered flow resistance at day 2 contribute to 
Table III. Dose and Time Dependence of Epidermal Proliferation Expressed as Epidermal Thickening Induced by Intradermal Injection of Angiotropin

\begin{tabular}{cccccc}
\hline & & \multicolumn{5}{c}{ Angiotropin dose } \\
\cline { 3 - 6 } $\begin{array}{c}\text { Time after } \\
\text { injection }\end{array}$ & Control & $1 \mathrm{ng} / \mathrm{ml}$ & $2.5 \mathrm{ng} / \mathrm{ml}$ & $5 \mathrm{ng} / \mathrm{ml}$ & $10 \mathrm{ng} / \mathrm{ml}$ \\
\hline$d$ & & & & & \\
2 & $14.8 \pm 1.6$ & ND & ND & $34.3 \pm 6.5$ & $40.7 \pm 8.3$ \\
3 & $19.2 \pm 2.6$ & $24.7 \pm 3.2$ & $32.9 \pm 2.2$ & $43.2 \pm 4.5$ & $54.7 \pm 12.6$ \\
4 & $15.7 \pm 0.9$ & $21.7 \pm 3.0$ & $30.1 \pm 6.0$ & $32.0 \pm 4.1$ & $44.2 \pm 3.8$ \\
6 & $14.8 \pm 2.4$ & ND & ND & $29.4 \pm 3.7$ & $37.1 \pm 6.6$ \\
10 & $15.4 \pm 1.9$ & ND & ND & $23.5 \pm 3.4$ & $28.7 \pm 3.5$
\end{tabular}

$50 \mu \mathrm{l}$ of angiotropin or control solution were injected intradermally. Thickness $(\mu \mathrm{m})$ of epidermis, excluding the stratum corneum, was determined in 5- $\mu \mathrm{m}$ paraffin sections stained with $\mathrm{H} \& \mathrm{E}$ by use of a MOP videoplan morphometric unit equipped with a microcomputer (Zeiss, Oberkochen, FRG). Mean values of 10 determinations in 5 rabbits \pm SD are given. the high RBC flux, which is then reduced by increasing flow resistance concomitantly with the decreasing vessel diameters at later stages. At day 8 the elevated blood cell flux may represent the increased number of microvessels with normal caliber.

Although laser Doppler flowmetry only measures red blood cell flux independent of the direction of the moving erythrocytes and, therefore, does not permit conclusions on functional aspects of the altered microcirculation in terms of nutritive flow, the data show that the microvascular changes follow defined dynamics and are dose dependent.

Histologically, endothelial cells of capillaries and postcapillary venules show phenotypical alterations during the phase of sinusoidal dilation. Within $24 \mathrm{~h}$ after injection of angiotropin the cells enlarge and elongate markedly, their prominent nuclei sometimes bulging into the vessel lumina. In addition, significant endothelial cell proliferation is evident in the dilated microvessels as shown in a 23-fold increase in thymidine labelling on day 2. Both the enlargement of the individual endothelial cells and endothelial proliferation seem to contribute to the vascular engorgement prior to neocapillarization.

Capillary angiogenesis appears at day 3 in the form of crops
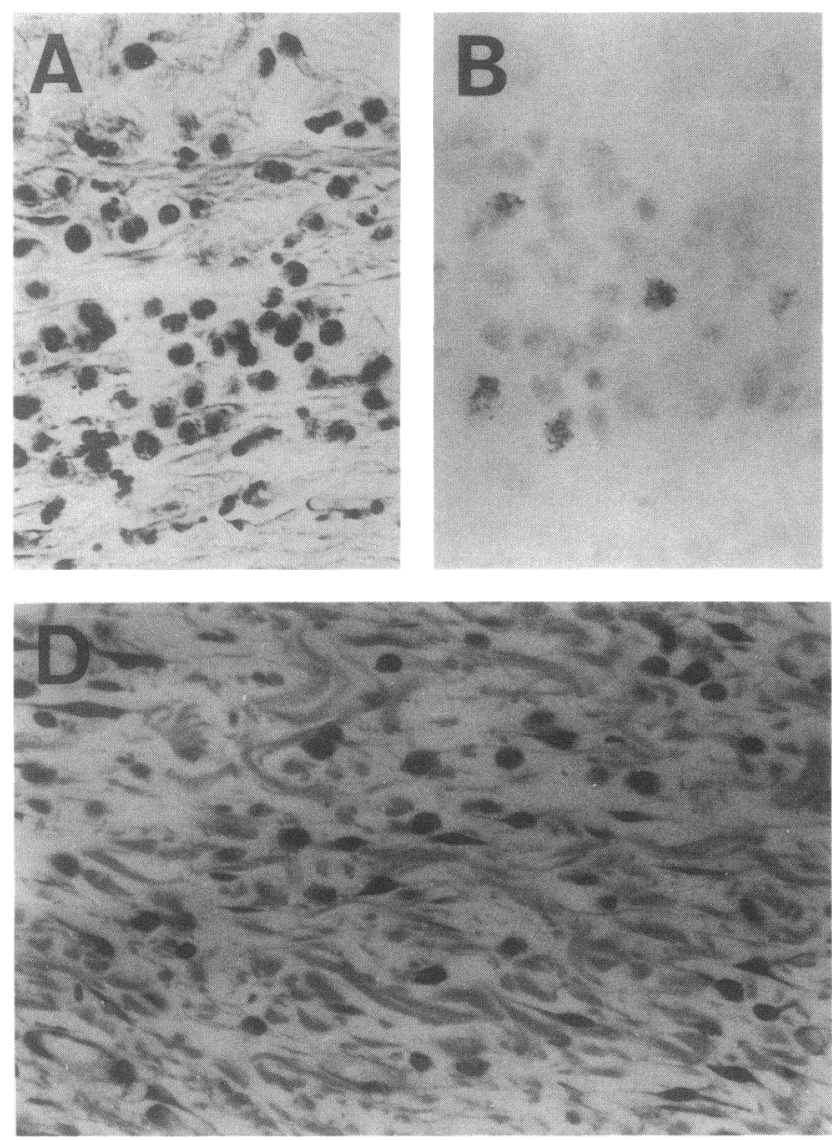

Figure 15. Dynamics of leukocytes and resident connective tissue cells after intradermal injection of angiotropin into the skin of rabbit ear lobes. (A) PMN leukocyte infiltration $12 \mathrm{~h}$ after the injection of $125 \mathrm{pg}$ of angiotropin in $50 \mu \mathrm{l}$ solution. (B) Mast cell accumulation at the site of angiotropin injection after $24 \mathrm{~h}$. (C) Unidentified perivascular cells which dominate in the stroma $2 \mathrm{~d}$ after injection of angiotropin; sinusoidally dilated microvessels are filled with india ink. (D) After $3 \mathrm{~d}$ most stromal cells are of fibroblastoid shapes contain-
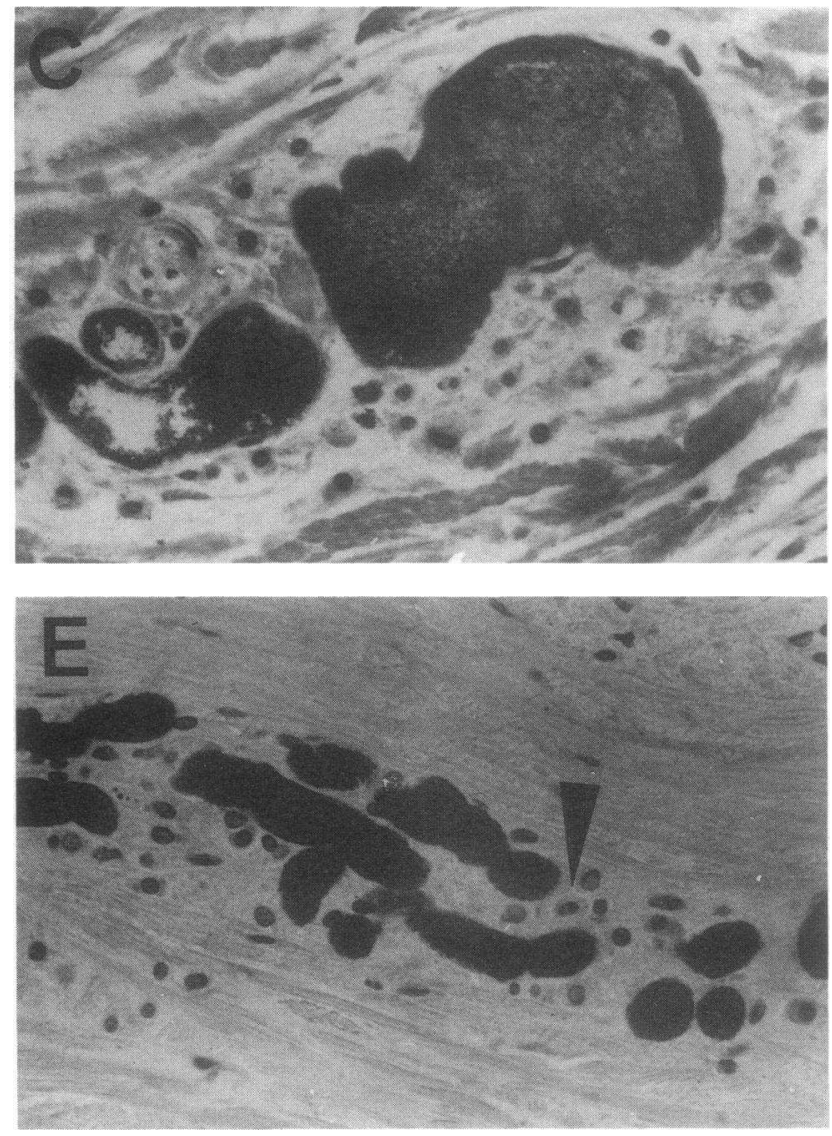

ing bipolar cytoplasmic processes. $(E)$ Accumulation of plasma cells and other small mononuclear cells around capillaries filled with india ink $8 \mathrm{~d}$ after injection of angiotropin; scattered eosinophilic granulocytes can also be detected at that time (arrowhead). $(A, D)$ H \& E stained paraffin sections; $\times 400,(C, E)$ H \& E stained plastic sections; $\times 400,(B)$ frozen section stained with toluidine blue/tetramethylene-glycol ether; $\times 630$. 

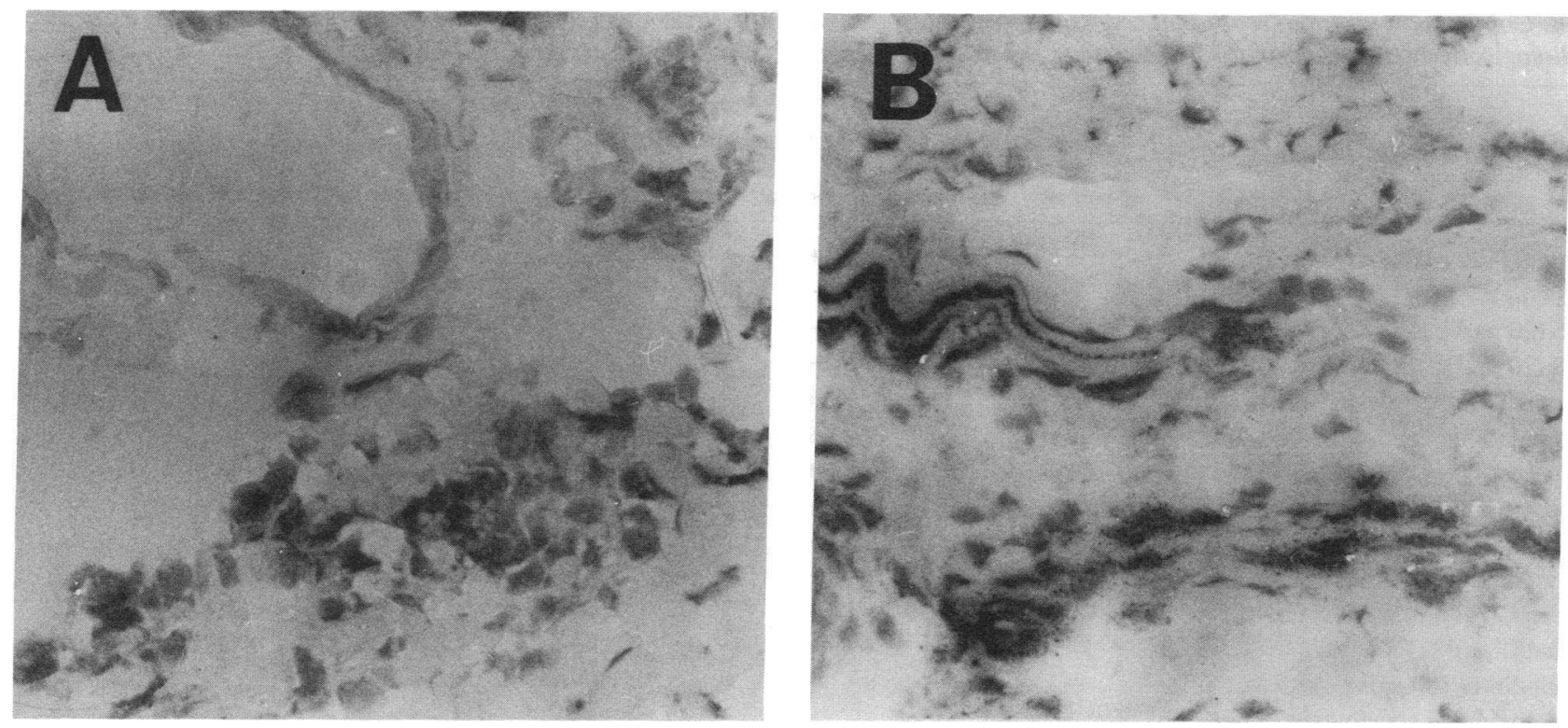

Figure 16. Nonspecific esterase enzyme-histochemistry showing no significant staining of the perivascular clusters of mononuclear cells on day 2 after intradermal injection of $125 \mathrm{pg}$ of angiotropin $(A)$ but pronounced staining of the macrophages in cord-like arrangement which are involved in the focal involution of blood vessels on day $4(B)$. Frozen sections; $\times 400$.

of minute capillary vessels or sprouts that apparently arise from the existing engorged blood vessels. ${ }^{1}$ The neocapillaries are initially devoid of erythrocytes which suggests that in their initial appearance their anastomotic connections are still functionally incomplete. Vascular proliferation and angiogenesis are temporary in the model chosen. Active regression is evident by day 4 as some of the microvessels undergo an inflammatory cell-mediated involution. Phagocytic macrophages appear to be the predominant cell type involved and the final vestige of the involuted vessel is the cord-like arrangement of vacuolated macrophages. This regressive process is similar to that described by Ausprunk et al. (33) for the regression of corneal neocapillaries after removal of the angiogenic stimulus. However, the amount of newly formed blood vessels exceeds the involuting ones within the observation period of this study. The morphometrical analysis clearly shows a net increase in capillaries on day 8 when histological signs of blood vessel regression are no longer seen.

In vitro angiotropin was shown to stimulate the differentiation of cloned capillary endothelial cells from the contactinhibited epitheloid phenotype to large fibroblastoid cells which migrate across each other and finally form tube-like structures on the tissue plate (23). An activation of endothelial cells in terms of nuclear and cytoplasmic enlargement and obvious suppression of contact inhibition are also seen in vivo early after angiotropin injection and might be interpreted as initial effect of that substance on endothelial cells.

The epidermal reaction to intradermal angiotropin is a transient hyperplasia in which all stages of epidermal growth and maturation are observed. The most striking features are found in the basal layer during the first $4 \mathrm{~d}$ after injection. Nuclear hyperchromasia, numerous mitoses, and a marked increase in $\left[{ }^{3} \mathrm{H}\right]$ thymidine incorporation in the basal layer in-

1. Capillary sprouts are clearly seen on day 3 during angiotropin-induced neovascularization in the cornea (23). dicate an active state of DNA synthesis and cell division. Mitoses that become much less prominent by day 3 suggest that maximum angiotropin stimulation occurs sometime in the first $2 \mathrm{~d}$ postinjection. The resultant basal cell hyperplasia in which there is extensive cell overcrowding in the basal zone appears to be sufficient evidence to explain the vertical cell displacement, the pseudostratification of basal nuclei, the downward pressure that causes the scallop configuration of the basement membrane and the overall thickening of the basal layer zone. By day 6 the basal pseudostratification and the basal nuclear changes disappear with the upward migration and differentiation of keratinocytes that comprise the prominent strata spinosum and granulosum. From the epidermal thickness measurements angiotropin induced epidermal hyperplasia appears to be a dose-dependent response.

Proliferative changes in the dermis after intradermal angiotropin are much less pronounced than those observed in the epidermis or the blood vessel. Unequivocal stroma hyperplasia is evidenced by the increased $\left[{ }^{3} \mathrm{H}\right]$ thymidine labeling of stromal cells and the appearance of numerous fibroblastoid cells at day 2 , respectively, day 3 . The pockets of loose connective tissue that appear in the reticular dermis about day 2 are the stromal sites where existing blood vessels undergo proliferation, where neocapillaries arise and where vascular involution takes place. The loose fibrillar arrangement of this connective tissue and the initial presence of reputed primitive mesenchymal cells suggest the possibility that focal resorption and/or modification of perivascular stroma is a prerequisite to neovascularization. The dermal matrix which is somewhat thickened at day 10 shows vague equivocal changes of individual collagen fibers, but there is no essential change in the normal basketweave configuration of stromal fibers. Single bolus angiotropin appears to initiate stromal cell hyperplasia but the production of new extracellular matrix (collagen and mucopolysaccharide) is not detected. Macroscopically and microscopically no evidence of scar formation is noticed. 
Table IV. Comparison of Angiotropin-induced Proliferative Response with the Reactions Obtained by Intradermal Injections of Various Other Biologically Inert, Inflammatory and Tissue Destructing Agents into the Rabbit Ear Skin

\begin{tabular}{|c|c|c|c|c|c|c|c|c|}
\hline & \multirow[b]{2}{*}{$\begin{array}{c}\text { Skin } \\
\text { necrosis }\end{array}$} & \multirow[b]{2}{*}{$\begin{array}{l}\text { Immediate } \\
\text { hyperemia }\end{array}$} & \multicolumn{3}{|c|}{$24 \mathrm{~h}$} & \multirow{2}{*}{$\begin{array}{c}\text { Day } 3 \\
\text { vascular } \\
\text { prominence }\end{array}$} & \multirow{2}{*}{$\begin{array}{c}\text { Day } 6 \\
\text { vascular } \\
\text { prominence }\end{array}$} & \multirow[b]{2}{*}{$\begin{array}{c}\text { Day } 10 \\
\text { neocapillarization }\end{array}$} \\
\hline & & & Hyperemia & Edema & $\begin{array}{c}\text { PMN } \\
\text { infiltration }\end{array}$ & & & \\
\hline Angiotropin (100 pg)* & - & - & +++ & + & ++ & ++ & + & + \\
\hline $\operatorname{Dexa}(200 \mu g)^{\ddagger}$ & - & $(+)$ & - & - & - & - & - & - \\
\hline $\operatorname{Dexa} C S(20 \mu \mathrm{g})^{\ddagger}$ & - & $(+)$ & - & - & - & - & - & - \\
\hline Dexa TS $(20 \mu \mathrm{g})^{\ddagger}$ & - & $(+)$ & - & - & - & - & - & - \\
\hline Angiotropin $(100 \mathrm{pg})^{*}+\operatorname{dexa}(200 \mu \mathrm{g})$ & - & $(+)$ & +++ & + & ++ & ++ & + & + \\
\hline Angiotropin $(100 \mathrm{pg})^{*}+$ dexa CS $(20 \mu \mathrm{g})$ & - & $(+)$ & +++ & + & ++ & ++ & $+(+)$ & $+(+)$ \\
\hline Angiotropin $(100 \mathrm{pg})^{*}+$ dexa TS $(20 \mu \mathrm{g})$ & - & $(+)$ & +++ & + & ++ & ++ & $+(+)$ & $+(+)$ \\
\hline Saline, isotonic & - & - & - & - & - & - & - & - \\
\hline PBS & - & - & - & - & - & - & - & - \\
\hline Wissler medium & - & - & - & - & - & - & - & - \\
\hline Porcine serum albumin $(0.25 \mathrm{mg} / \mathrm{ml})^{\ddagger}$ & - & - & - & - & - & - & - & - \\
\hline Histamine $(1 \mu \mathrm{g})^{\ddagger}$ & - & +++ & - & - & - & - & - & - \\
\hline Prostaglandin $\mathrm{E}_{2}(50 \mu \mathrm{g})^{\ddagger}$ & - & +++ & - & - & - & - & - & - \\
\hline Anaphylatoxin and cocytotaxin $(5 \mathrm{ng} / 5 \mathrm{ng})^{\ddagger}$ & - & + & + & - & $(+)^{1}$ & - & - & - \\
\hline Cocytotaxin $(5 \mathrm{ng})^{\ddagger}$ & - & - & - & - & - & - & - & - \\
\hline Concanavalin $\mathrm{A}(250 \mathrm{pg})^{\ddagger}$ & - & - & - & - & - & - & - & - \\
\hline Concanavalin A $(15 \mu \mathrm{g})^{\ddagger}$ & $(+)$ & + & ++ & ++ & $++(+)$ & + & - & - \\
\hline Concanavalin A $(150 \mu \mathrm{g})^{\ddagger}$ & ++ & + & +++ & +++ & +++ & + & + & $(+)$ \\
\hline Hypotonic pyrogen-free water & - & +++ & +++ & ++ & ++ & $(+)$ & - & - \\
\hline Saline $1.5 \mathrm{M}$ & - & +++ & ++ & + & + & - & - & - \\
\hline Formic acid $0.2 \%$ & + & + & + & + & + & + & ++ & + \\
\hline Pentobarbital (3 mg) & ++ & +++ & +++ & +++ & + & ++ & ++ & ++ \\
\hline Sodium hydroxide (1 N) & +++ & + & ++ & ++ & ++ & ++ & +++ & ++ \\
\hline
\end{tabular}

* Dissolved in PBS + porcine serum albumin $(0.25 \mathrm{mg} / \mathrm{ml}) . \quad{ }^{\ddagger}$ Dissolved in PBS. Dexa, dexamethasonedihydrogenphosphate; dexa CS, dexamethasoneacetate crystal suspension; dexa TS, dexamethasoneacetate therapeutic system. ' Severe PMN infiltration occurred $2 \mathrm{~h}$ after injection. All solutions were injected intradermally as $50 \mu \mathrm{l}$ bolus as described in Methods. All experiments were performed at least in duplicate. To exclude local interference usually no more than three injections were made per rabbit ear. Reactions were screened by daily macroscopic observations until day 10 and microscopic evaluation of $24 \mathrm{~h}$ histologic sections. Angiogenesis was proven macroscopically by the presence of numerous prominent congested irregular or tortuous vessels at the site of injection ("vascular prominence") before the increase of capillary density detected by homogenous slight redness with changing intensity according to the fluctuations in whole ear perfusion ("neocapillarization"). In cases of gross skin necrosis the tissue reaction adjacent to the damaged skin area was evaluated.

Although tissue destruction does not precede the proliferative tissue response, the reaction induced by intradermal angiotropin is associated with a defined turnover of inflammatory cells and resident connective tissue cells. A transient influx of PMN leukocytes is found in the angiotropin injection site within the first $24 \mathrm{~h}$. Angiotropin has been shown to be neither chemotactic nor chemokinetic for porcine and rabbit leukocytes in vitro (34). The kinetics of PMN leukocyte influx for a number of known PMN chemotaxins and chemotaxinogens including endotoxin (35) differ from the PMN leukocyte kinetics observed in this study. The injection of PMN leukocytes into rabbit cornea does not produce neovascularization and the ability of PMN leukocytes to induce direct neovascularization is questioned by others (36). These data suggest that transient influx of PMN leukocytes is a secondary response to the vascular alterations induced by angiotropin and that the presence of PMN leukocytes is not the stimulus for neovascularization and cell proliferation.

As shown by enzyme-histochemistry, monocytes/macrophages are not prominent on days 1 and 2 when cellular proliferation within the injection site of angiotropin is maximal.
These cells increase in number on day 3 and are most frequent on day 4 when regression phenomena can be observed. The injection of dexamethasone in both short- and long-term regimens fails to block or inhibit the in vivo angiogenic effects of angiotropin. Angiogenesis due to unspecific inflammation probably mediated by macrophages can be inhibited by dexamethasone (37), and corticosteroids are known to cause delay in wound healing by inhibiting macrophage functions (11). Therefore, a role of macrophages in mediating the angiogenic effects of intradermal angiotropin might be questioned as well. Nevertheless, a potential function of PMN or mononuclear inflammatory cells within the complex cascade of proliferative tissue reactions induced by angiotropin cannot be excluded at present.

Copper ions and various other substances may cause angiogenesis by chronic inflammation $(38,39)$. Contrary to angiotropin these substances have to be applied in relatively high concentrations and by a slow release system to exert angiogenic effects in the corneal pocket assay. Moreover, neovascularization of these substances can be blocked effectively by corticosteroids. These differences exclude an explanation of 
the angiogenic action of angiotropin simply by effects of its copper constituent.

The various control substances in this study fail to induce neovascularization when injected into the rabbit ear skin except when injections were accompanied by tissue necrosis. Necrosis, but not acute inflammation, therefore appears to be the common pathway by which these substances produce neovascularization in the "single bolus injection model." Angiotropin is the only substance in this study which induces neovascularization and tissue proliferation in the absence of tissue necrosis.

Taken together, the results of this study with regard to the in vitro work (23) suggest that angiotropin is a direct mediator of a microvascular process that leads to angiogenesis and involves the release of inflammatory cells.

The mechanisms by which intradermal angiotropin induces the proliferation of the various cell types in the skin are not known at present. Although there appears to be a dose-dependent relationship, the proliferative reactions of endothelial cells, fibroblasts and epidermal cells might be secondary effects due to the activation of microvascular endothelial cells because of the following findings: (a) Angiotropin is a differentiation factor but not a mitogen for capillary endothelial cells in vitro (23). (b) Angiotropin did not produce any effects on BALB/c3T3 fibroblasts in vitro (23). (c) After implantation of an angiotropin-containing Elvax pellet in the rabbit cornea epithelial hyperplasia was found in projection of the activated limbal vessels but not adjacent to the slow release system (unpublished observations). Principally, the cellular proliferation might be caused by humoral factors, autocrine or paracrine secretion of growth factors, modulation of extracellular matrix components or changes in cell-to-cell-junctions following the activation of endothelial cells with angiotropin.

Low molecular weight fibrin degradation products have been shown to induce angiogenesis and the proliferation of all cell types in the chicken chorioallantoic membrane (40). Extravascular fibrin deposits are occasionally found in angiotropin injection sites on day 1 , however, the role and contribution of fibrin degradation products in angiotropin induced proliferation is unknown. Most of the angiotropin injection sites are free of detectable interstitial or extravascular fibrin, which suggests that the actions of angiotropin take place independently of fibrin degradation products.

Recently, Folkman and co-workers suggested a very interesting mechanism for local control of cell proliferation that involves the liberation of growth factors stored in the extracellular matrix $(41,42)$. Marked changes in extracellular matrix, especially basement membranes of microvessels and epidermis, are early observations after intradermal injection of angiotropin.

In conclusion, we have attempted to characterize the in vivo effects of angiotropin using a "single bolus-rabbit ear model." We have found profound vascular alterations consisting of initial microvascular endothelial cell activation and microvessel engorgement, followed by neocapillarization as well as associated proliferative responses in the epidermis, the dermis, and the activation of resting hair follicles. In our model, tissue proliferation is transient and most of the proliferative effects regress through a series of involutional events within the observation time of $12 \mathrm{~d}$. During the tissue reaction a defined turnover of inflammatory cells can be observed but tissue necrosis and scar formation are not detected. The in- duced reactions show time-lapsed similarities to the skin alterations adjacent to a deep wound in the inflammatory/proliferative phase of primary healing (43-47). We suggest therefore, that angiotropin is a chemical mediator by which the activated macrophage initiates a cascade of inflammatory and proliferative wound healing sequences through activation of microvascular endothelial cells. Because of the dose dependency and defined dynamics of the induced tissue reactions this substance may also be a promising therapeutic agent in clinical settings where wound healing is a major problem. We have recently shown that angiotropin may prevent skin flap necrosis and stimulates dermal regeneration in preclinical studies (48).

\section{Acknowledgments}

We are very grateful to Ms. U. Merkel, Anatomisches Institut, and Ms. H. Weber-Wolf, Universitätsfrauenklinik Mainz, W. Germany, and Ms. B. Lusetti, Shriners Burns Hospital, Boston, MA, for their engaged help and excellent work in performing most of the histologic preparations for this study. We also thank Ms. M. Metzger, R. Kerler, B. Berning, and B. Sickert, Pathologisches Institut, München, W. Germany, for the autoradiographic processing. We thank Dr. P. Ehrlich, Harvard Medical School, Shriners Burns Hospital, Boston, for providing us with the laser Doppler capillary perfusion monitor. M.H. is indebted to Professor Dr. V. Friedberg, Universitätsfrauenklinik Mainz, and to Professor Dr. J. F. Burke, Harvard Medical School, for many discussions and generous support of this study.

\section{References}

1. Bullough, W. S., and E. B. Laurence. 1960. The control of epidermal mitotic activity in the mouse. Proc. R. Soc. Biol. 151:517536.

2. Carrel, A. 1922. Growth-promoting function of leucocytes. $J$. Exp. Med. 36:385-391.

3. Abercrombie, M. 1957. Localized formation of new tissue in an adult mammal. In The Biological Action of Growth Substances. (Symp. of the Society for Exper. Biol. No. 11.) Academic Press, New York. 235-254.

4. Swann, M. M. 1958. The control of cell division: A review. II. Special mechanisms. Cancer Res. 18:1118-1160.

5. Clark, E. R., and E. L. Clark. 1939. Microscopic observations on the growth of blood capillaries in the living mammal. Am. J. Anat. 64:251-301.

6. Ingber, D. E., and J. D. Jamieson. 1982. Tumor formation and malignant invasion: role of basal lamina. In Tumor Invasion and Metastasis. L. A. Liotta and I. R. Hart, editors. Martinus Nijhoff, Publisher, The Hague. 335-357.

7. Martin, B. M., M. A. Gimbrone, E. R. Unanue, and R. S. Cotran. 1981. Stimulation of nonlymphoid mesenchymal cell proliferation by a macrophage-derived growth factor. J. Immunol. 126:15101515.

8. Glenn, K. C., and R. Ross. 1981. Human monocyte-derived growth factor(s) for mesenchymal cells. Activation of secretion by endotoxin and concanavalin A. Cell. 25:603-615.

9. Wharton, G., Y. Gillespie, S. W. Russell, and W. J. Pledger. 1982. Mitogenic activity elaborated by macrophage like cell lines acts as competence factor(s) for Balb/c3T3 cells. J. Cell. Physiol: 110:93100.

10. Werb, Z. 1983. How the macrophage regulates its extracellular environment. Am. J. Anat. 166:237-256.

11. Leibovich, S. J., and R. Ross. 1975. The role of the macrophage in wound repair: a study with hydrocortisone and antimacrophage serum. Am. J. Pathol. 78:71-100. 
12. Clark, R. A., R. D. Stone, D. Y. K. Leung, D. C. Silver, and D. C. Hahn. 1976. Role of macrophages in wound healing. Surg. Forum. 27:16-18.

13. Polverini, P. J., R. S. Cotran, M. A. Gimbrone, and E. R. Unanue. 1977. Activated macrophages induce vascular proliferation. Nature (Lond.). 269:804-806.

14. Thakral, K. K., W. H. Goodson, and T. K. Hunt. 1979. Stimulation of wound blood vessel growth by wound macrophages. J. Surg. Res. 26:430-436.

15. Leibovich, S. J., and R. Ross. 1976. A macrophage-dependent factor that stimulates the proliferation of fibroblasts in vitro. Am. J. Pathol. 84:501-513.

16. Leibovich, S. J. 1984. Mesenchymal cell proliferation in wound repair: the role of macrophages. In Soft and Hard Tissue Repair. T. K. Hunt, R. B. Heppleston, E. Pines, and D. Rovee, editors. Praeger Press, New York. 329-351.

17. Leibovich, S. J., and P. J. Polverini. 1985. Partial purification of macrophage-derived growth factor (MDGF) and macrophage-derived angiogenic activity (MDAA) by gel filtration high-pressure liquid chromatography. Br. J. Rheumatol. 24(suppl 1):197-202.

18. Baird, A., P. Mormede, and P. Bohlen. 1985. Immunoreactive fibroblast growth factor in cells of peritoneal exudate suggest its identity with macrophage derived growth factor. Biochem. Biophys. Res. Commun. 126:358-364.

19. Knighton, D. R., I. A. Silver, and T. K. Hunt. 1981. Regulation of wound-healing angiogenesis: effect of oxygen gradients and inspired oxygen concentration. Surgery (St. Louis). 90:262.

20. Knighton, D. R., T. K. Hunt, H. Scheuenstuhl, B. J. Halliday, Z. Werb, and M. J. Banda. 1983. Oxygen tension regulates the expression of angiogenesis factor by macrophages. Science (Wash. DC). 221:1283-1285.

21. Wissler, J. H., and H. Renner. 1981. Inflammation, chemotropisms and morphogenesis: novel leukocyte-derived mediators for directional growth of blood vessels and regulation of tissue neovascularization. Z. Physiol. Chem. 362:244.

22. Wissler, J. H., E. Logemann, H. E. Meyer, B. Krützfeld, M. Höckel, and L. M. G. Heilmeyer. 1986. Structure and function of a monocytic blood vessel morphogen (angiotropin) for angiogenesis in vivo and in vitro: a copper-containing metallo-polyribonucleo-polypeptide as a novel and unique type of monokine. Protides Biol. Fluids. 34:525-536.

23. Höckel, M., J. Sasse, and J. H. Wissler. 1987. Purified monocyte-derived angiogenic substance (angiotropin) stimulates migration, phenotypic changes and "tube formation" but not proliferation of capillary endothelial cells in vitro. J. Cell. Physiol. 133:1-13.

24. Wissler, J. H. 1972. Chemistry and biology of the anaphylatoxin related serum peptide system. II. Purification, crystallization and properties of cocytotaxin, a basic peptide from rat serum. Eur. J. Immunol. 2:84-89.

25. Garvey, W. 1984. Modified elastic tissue-Masson trichrome stain. Stain Technol. 59:213-216.

26. Koski, I. R., D. G. Poplack, and R. M. Blaese. 1976. A nonspecific esterase stain for the identification of monocytes and macrophages. In In vitro methods in cell-mediated and tumor immunity. B. R. Bloom, and J. R. David, editors. Academic Press, New York. 359-362.

27. Ehrlich, H. P., T. R. Griswold, and J. Rajaratnam. 1986. ATPinduced cell contraction with epidermolysis bullosa dystrophica recessive and normal dermal fibroblasts. J. Invest. Dermatol. 86:96-100.

28. Padawer, J. 1959. A stain for mast cells and its application in various vertebrates and in a mastocytoma. J. Histochem. Cytochem. 7:353.

29. Falck, B., N. A. Hillarp, G. Thieme, and A. Torp. 1962. Fluorescence of catecholamines and related compounds condensed with formaldehyde. J. Histochem. Cytochem. 10:348-354.
30. Höckel, M., T. Beck, and J. H. Wissler. 1984. Neomorphogenesis of blood vessels in rabbit skin induced by a highly purified monocyte-derived polypeptide (monocyto-angiotropin) and associated tissue reactions. Int. J. Tissue Reactions 6:323-331.

31. Höckel, M., S. Ott, U. Siemann, and T. Kissel. 1987. Prevention of peritoneal adhesions in the rat with sustained intraperitoneal dexamethasone delivered by a novel therapeutic system. Ann. Chir. Gyn. 76:306-313.

32. Brain, S. D., T. J. Williams, J. R. Tippins, H. R. Morris, and I. MacIntyre. 1985. Calcitonin gene-related peptide is a potent vasodilator. Nature (Lond.). 313:54-56.

33. Ausprunk, D. H., K. Falterman, and J. Folkman. 1978. The sequence of events in the regression of corneal capillaries. Lab. Invest. 38:284-294.

34. Höckel, M., J. Sasse, and J. H. Wissler. 1986. Mechanisms in angiogenesis action of a monocytic blood vessel morphogen (angiotropin): in vitro studies on motility, differentiation and spatial organization of cloned capillary endothelial cells. Protides Biol. Fluids. 34:517-524.

35. Colditz, I. G., and H. Z. Movat. 1984. Kinetics of neutrophil accumulation in acute inflammatory lesions induced by chemotaxins and chemotaxinogens. J. Immunol. 133:2169-2173.

36. Moore, J. W., and M. M. Sholley. 1985. Comparison of the neovascular effects of stimulated macrophages and neutrophils in autologous rabbit corneas. Am. J. Pathol. 120:87-94.

37. Tsukamoto, K., and Y. Sugino. 1979. Tumor angiogenesis activity in clonal cells transformed by bovine adenovirus type 3 . Cancer Res. 39:1305-1309.

38. Ziche, M., J. Jones, and P. M. Gullino. 1982. Role of prostaglandin $\mathrm{E}_{1}$ and copper in angiogenesis. J. Natl. Cancer. Inst. 69:475482.

39. McAuslan, B. R., W. G. Reilly, G. N. Hannan, and G. D. Gole. 1983. Angiogenic factors and their assay: Activity of formyl methionyl leucyl phenylalanine, adenosine diphosphate, heparin, copper, and bovine endothelium stimulating factor. Microvasc. Res. 26:323-338.

40. Thompson, W. D., R. Campbell, and T. Evans. 1985. Fibrin degradation and angiogenesis: quantitative analysis of the angiogenic response in the chick chorioallantoic membrane. J. Pathol. 145:27-37.

41. Folkman, J., and M. Klagsbrun. 1987. Angiogenic factors. Science (Wash. DC). 235:442-447.

42. Vlodavsky, I., J. Folkman, R. Sullivan, R. Fridman, R. IshaiMichaeli, J. Sasse, and M. Klagsbrun. 1987. Endothelial cell derived basic fibroblast growth factor: synthesis and deposition into subendothelial extracellular matrix. Proc. Natl. Acad. Sci. USA. 84:2292-2296.

43. Karppinen, V., and H. Myllärniemi. 1967. The vascular supply of healing wound. Acta Pathol. Microbiol. Scand. 71:59-67.

44. Myers, M. B., and G. Cherry. 1971. Blood supply of healing wounds: Functional and angiographic. Arch. Surg. 102:49-52.

45. Leibovich, S. J. 1984. Mesenchymal cell proliferation in wound repair: the role of macrophages. In Soft and Hard Tissue Repair. T. K. Hunt, R. B. Heppleston, E. Pines, and D. Rovee, editors. Praeger Press, New York. 329-351.

46. Argyris, T. S. 1964. Wound healing and the control of growth of the skin. In Advances in Biology of Skin. Vol. 5. Wound Healing. W. Montagna, and R. E. Billingham, editors. Proceedings of the Brown University, Symposium of the Biology of Skin. Pergamon Press, New York. 231-249.

47. Glücksmann, A. 1964. Cell turnover in the dermis. In Advances in Biology of Skin. Vol. 5. Wound Healing. W. Montagna, and R. E. Billingham, editors. Proceedings of the Brown University, Symposium of the Biology of Skin. Pergamon Press, New York. 76-112.

48. Höckel, M., and J. F. Burke. 1988. Angiotropin prevents flap necrosis and enhances dermal regeneration in rabbits. Arch. Surg. In press. 